\title{
Interpopulational differences in the nutritional condition of Aequiyoldia eightsii (Protobranchia: Nuculanidae) from the Western Antarctic Peninsula during austral summer
}

\author{
Miguel Bascur ${ }^{\text {Corresp., } 1,2}$, Simon A Morley ${ }^{3}$, Michael P Meredith ${ }^{3}$, Carlos Muñoz-Ramírez ${ }^{4}$, David KA Barnes ${ }^{3}$, Iren \\ R Schloss ${ }^{5,6,7}$, Chester J Sands $^{3}$, Oscar Schofield ${ }^{8}$, Alejandro Román-González ${ }^{9}$, Leyla Cárdenas ${ }^{10,11}$, Hugh \\ Venables $^{3}$, Antonio Brante ${ }^{1,12}$, Ángel Urzúa ${ }^{1,12}$ \\ ${ }^{1}$ Departamento de Ecología, Facultad de Ciencias, Universidad Católica de la Santísima Concepción, Concepción, Chile \\ 2 Programa de Magister en Ecología Marina, Universidad Católica de la Santísima Concepción, Concepción, Chile \\ 3 British Antarctic Survey, Natural Environment Research Council, Cambridge, United Kingdom \\ 4 Instituto de Entomología, Universidad Metropolitana de Ciencias de la Educación, Santiago, Chile \\ 5 Instituto Antártico Argentino, Buenos Aires, Argentina \\ 6 Centro Austral de Investigaciones Científicas (CADIC-CONICET), Ushuaia, Argentina \\ 7 Universidad Nacional de Tierra del Fuego, Ushuaia, Argentina \\ 8 Center for Ocean Observing Leadership, Department of Marine and Coastal Sciences, School of Environmental and Biological Sciences, Rutgers \\ University, New Brunswick, United States \\ 9 College of Life and Environmental Sciences, University of Exeter, Cornwall, United Kingdom \\ 10 Centro FONDAP de Investigación en Dinámica de Ecosistemas Marinos de Altas Latitudes (IDEAL), Valdivia, Chile \\ 11 Instituto de Ciencias Ambientales y Evolutivas, Facultad de Ciencias, Universidad Austral de Chile, Valdivia, Chile \\ 12 Centro de Investigación en Biodiversidad y Ambientes Sustentables (CIBAS), Universidad Católica de la Santísima Concepción, Concepción, Chile \\ Corresponding Author: Miguel Bascur \\ Email address: mbascur@magister.ucsc.cl
}

The Western Antarctic Peninsula (WAP) is a hotspot for environmental change and has a strong environmental gradient from North to South. Here, for the first time we used adult individuals of the bivalve Aequiyoldia eightsii to evaluate large-scale spatial variation in the biochemical composition (measured as lipid, protein and fatty acids) and energy content, as a proxy for nutritional condition, of three populations along the WAP: O'Higgins Research Station in the north $\left(63.3^{\circ} \mathrm{S}\right)$, Yelcho Research Station in mid-WAP $\left(64.9^{\circ} \mathrm{S}\right)$ and Rothera Research Station further south $\left(67.6^{\circ} \mathrm{S}\right)$. The results reveal significantly higher quantities of lipids $(L)$, proteins $(P)$, energy $(E)$ and total fatty acids $(F A)$ in the northern population (O'Higgins) (L: $8.33 \pm 1.32 \%$; P: $22.34 \pm 3.16 \%$; E: $171.53 \pm 17.70$ Joules; FA: $16.33 \pm 0.98 \mathrm{mg} \mathrm{g}$ ) than in the mid-WAP population (Yelcho) (L: $6.23 \pm 0.84 \%$; P: $18.63 \pm$ 1.17\%; E: $136.67 \pm 7.08$ Joules; FA: $10.93 \pm 0.63 \mathrm{mg} \mathrm{g}$ ) and southern population (Rothera) (L: $4.60 \pm 0.51 \% ; P: 13.11 \pm 0.98 \% ; E: 98.37 \pm 5.67$ Joules; FA: $7.58 \pm 0.48 \mathrm{mg}$ g). We hypothesize these differences in the nutritional condition could be related to a number of biological and environmental characteristics. Our results can be interpreted as a consequence of differences in phenology at each location; differences in somatic and 
gametogenic growth rhythms. Contrasting environmental conditions throughout the WAP such as seawater temperature, quantity and quality of food from both planktonic and sediment sources, likely have an effect on the metabolism and nutritional intake of this species. 
2 Interpopulational differences in the nutritional condition of 3 Aequiyoldia eightsii (Protobranchia: Nuculanidae) from the 4 Western Antarctic Peninsula during austral summer

Miguel Bascur ${ }^{1,2}$, Simon A. Morley ${ }^{3}$, Michael P. Meredith ${ }^{3}$, Carlos Muñoz-Ramírez ${ }^{4}$, David KA Barnes $^{3}$, Irene R. Schloss ${ }^{5,6,7}$, Chester J. Sands ${ }^{3}$, Oscar Schofield ${ }^{8}$, Alejandro Román-Gonzalez ${ }^{9}$, Leyla Cárdenas ${ }^{10,11}$, Hugh Venables ${ }^{3}$, Antonio Brante ${ }^{1,12}$, Ángel Urzúa ${ }^{1,12}$

${ }^{1}$ Departamento de Ecología. Facultad de Ciencias. Universidad Católica de la Santísima

${ }^{2}$ Programa de Magíster en Ecología Marina. Universidad Católica de la Santísima Concepción,

14 Concepción, Chile

${ }^{3}$ British Antarctic Survey, Natural Environment Research Council, Cambridge, United Kingdom

${ }^{4}$ Instituto de Entomología, Universidad Metropolitana de Ciencias de la Educación, Santiago, Chile

${ }^{5}$ Instituto Antártico Argentino, 25 de mayo 1143, San Martín, Buenos Aires, Argentina

${ }^{6}$ Centro Austral de Investigaciones Científicas (CADIC-CONICET), Bernardo Houssay 200, Ushuaia, Tierra del Fuego, Argentina USA

${ }^{9}$ College of Life and Environmental Sciences, University of Exeter, Penryn, Cornwall, United

${ }^{10}$ Centro FONDAP de Investigación en Dinámica de Ecosistemas Marinos de Altas Latitudes (IDEAL), Valdivia, Chile

${ }^{11}$ Instituto de Ciencias Ambientales y Evolutivas, Facultad de Ciencias, Universidad Austral de Chile, Valdivia, Chile

${ }^{12}$ Centro de Investigación en Biodiversidad y Ambientes Sustentables (CIBAS). Universidad Católica de la Santísima Concepción, Concepción, Chile

Corresponding Author:

Miguel Bascur 
39

40

41

42

43

44

45

46

47

48

49

50

51

52

53

54

55

56

57

58

59

60

61

62

63

64

65

66

67

68

69

70

71

72

73

74

75

76

77

78

\section{Abstract}

The Western Antarctic Peninsula (WAP) is a hotspot for environmental change and has a strong environmental gradient from North to South. Here, for the first time we used adult individuals of the bivalve Aequiyoldia eightsii to evaluate large-scale spatial variation in the biochemical composition (measured as lipid, protein and fatty acids) and energy content, as a proxy for nutritional condition, of three populations along the WAP: O'Higgins Research Station in the north $\left(63.3^{\circ} \mathrm{S}\right)$, Yelcho Research Station in mid-WAP $\left(64.9^{\circ} \mathrm{S}\right)$ and Rothera Research Station further south $\left(67.6^{\circ} \mathrm{S}\right)$. The results reveal significantly higher quantities of lipids (L), proteins $(\mathrm{P})$, energy (E) and total fatty acids (FA) in the northern population (O'Higgins) (L: $8.33 \pm$ 1.32\%; P: $22.34 \pm 3.16 \%$; E: $171.53 \pm 17.70$ Joules; FA: $16.33 \pm 0.98 \mathrm{mg}$ g) than in the midWAP population (Yelcho) (L: $6.23 \pm 0.84 \%$; P: $18.63 \pm 1.17 \%$; E: $136.67 \pm 7.08$ Joules; FA: $10.93 \pm 0.63 \mathrm{mg} \mathrm{g}$ ) and southern population (Rothera) (L: $4.60 \pm 0.51 \%$; P: $13.11 \pm 0.98 \%$; E: $98.37 \pm 5.67$ Joules; FA: $7.58 \pm 0.48 \mathrm{mg}$ g). We hypothesize these differences in the nutritional condition could be related to a number of biological and environmental characteristics. Our results can be interpreted as a consequence of differences in phenology at each location; differences in somatic and gametogenic growth rhythms. Contrasting environmental conditions throughout the WAP such as seawater temperature, quantity and quality of food from both planktonic and sediment sources, likely have an effect on the metabolism and nutritional intake of this species.

\section{Introduction}

Nutritional condition is a key biological response to environmental change, since it is a factor that is expected to limit the capacity of a diverse range of biological mechanisms to respond to biotic and abiotic variability (Somero, Lockwood \& Tomanek, 2017). On the one hand, in important aquatic species for aquaculture and fisheries, nutritional condition has generally been analyzed through multiple methods such as DNA:RNA, proximate composition and fatty acids (Tacon \& Metian, 2013; Tan et al., 2021). In these studies, nutritional condition has been used as an indicator of food quality for human consumption, since it allows detection of molecules with high nutritional value (Lah et al., 2017; Lorenzo et al., 2021). On the other hand, in ecological studies, nutritional condition has great potential to be used as an indicator of the energy reserves of aquatic organisms (Vesterinen et al., 2020; Bascur et al., 2020). For instance, a recent study on the Antarctic bivalve Nuculana inaequisculpta found differences in the nutritional condition of individuals on a transect away from a retreating glacier in a small WAP fjord (Bascur et al., 2020), and consistent with variation in other population attributes such as genetic diversity (Muñoz-Ramírez et al., 2021). However, understanding of how nutritional condition of different populations of marine invertebrate species vary in response to prevailing environmental conditions at large spatial scales is still very limited in Antarctic ecosystems.

Biochemical composition has been widely investigated in a range of marine bivalve species from high and low latitude ecosystems (e.g. Ahn et al., 2003; Pogoda et al., 2013). Lipids, protein, carbohydrates and fatty acids all have crucial roles in development, metabolism and 
79 functioning of marine organisms (Somero, Lockwood \& Tomanek, 2017). In species with a wide 80 geographic distribution, these biochemical reserves can be modified by abiotic factors such as 81 sea temperature or food availability (Guzmán-Rivas et al., 2021). However, biotic factors can 82 also play an important role. For example, it has been shown that there is a close relationship 83 between biochemical composition and reproduction in marine invertebrates, since there is a 84 significant expenditure of biochemical reserves in the production of gametes, which are released 85 at the time of spawning (Mathieu \& Lubet 1993; Darriba, Juan \& Guerra, 2005; Ngo et al., 2006; 86 Li et al., 2011). In this way, it is necessary to consider reproductive status when the reproductive 87 cycle is not known with certainty, or there is no information available on gonad maturity of the 88 samples. Accordingly, species biochemical composition and energy content can be used as an 89 indicator to compare the nutritional condition among different benthic populations. For this 90 purpose, the WAP constitutes a valuable natural laboratory in which to evaluate biological 91 92 variables on a large spatial scale, potentially improving understanding of biological patterns across a contrasting environmental gradient (Barnes et al., 2020; Zwerschke et al., 2021).

The study species, Aequiyoldia eightsii (Jay, 1839), is an infaunal bivalve mollusk of the Protobranchia subclass, distributed patchily in Antarctic and sub-Antarctic areas with muddy sediments (Dell, 1991; González-Wevar et al., 2012). A. eightsii is a long-lived species with a maximum lifespan around 60 years (Nolan \& Clarke, 1993; Peck \& Bullough, 1993; RománGonzález et al., 2017). This abundant species can be found from intertidal to deep waters, although it is more frequent at depths less than $100 \mathrm{~m}$, with densities of up to 1540 individual m-2 (Peck \& Bullough, 1993). It has been described as an opportunistic species, since it feeds mainly

100

101

102

103

104

105

106

107

108

109

110

111

112

113

114

115

116

117

118 on organic sediment deposits (Zardus, 2002). However, it can modify its feeding habits by ingesting suspended particles when phytoplankton is available (Davenport, 1988a). Recent studies found an endogenous growth rhythm in this species, likely related to reallocation of energy investment towards growth or reproduction (Román-González et al., 2017). A. eightsii shows a 1:1 male: female sex ratio and a lecithotrophic pericalima larva (Zardus, 2002). At South Orkney Islands $\left(61^{\circ} \mathrm{S}\right)$, individuals of this species reach their sexual maturity when shell length is $>20 \mathrm{~mm}$ (Peck, Colman \& Murray, 2000). Further south, at Rothera Station, A. eightsii showed continuous oogenesis throughout the year with spawning in austral winter (Lau et al., 2018).

Clear patterns of sea ice, seawater temperature, primary productivity and other relevant factors as well as biological change along the environmental gradient at the WAP have been extensively reported (Henley et al., 2019; Morley et al., 2020; Rogers et al., 2020). The mean annual sea-ice duration, defined as the mean number of months per year with an ice concentration higher than $50 \%$, is quite different across the WAP (Smith et al., 2012). For example, in the north this sea ice condition lasts on average about 1-2 months per year, while in the middle of the WAP it lasts about 4 months. In contrast, in the south of the WAP this sea ice condition lasts around 5.5 months per year (Smith et al., 2012). In turn, the surface seawater temperature $(10 \mathrm{~m})$ during the summer season shows a clear latitudinal gradient along the WAP, with temperatures between 1$1.5^{\circ} \mathrm{C}$ in the north, temperatures between $1-1.25^{\circ} \mathrm{C}$ in the middle and temperatures between 0.5 - 
$1190.75^{\circ} \mathrm{C}$ in the south of the WAP (Schloss et al., 2012; Cook et al., 2016). Regarding

120

121

122

123

124

125

126

127

128

129

130

131

132

133

134

135

136

137

138

139

140

141

142

143

144

145

146

147

148

149

150

151

152

153

154

155

156

157

phytoplankton biomass, Kim et al., (2018) also reported contrasting values during the summer along the WAP. Phytoplankton biomass values between 1-2 $\mu \mathrm{g} \mathrm{L}^{-1}$ in the north, biomass values between $2-5 \mu \mathrm{g} \mathrm{L}^{-1}$ in the middle, and values close to $4.5-6 \mu \mathrm{g} \mathrm{L}^{-1}$ in the south of the WAP have been observed (Kim et al., 2018).

This research provides information on nutritional condition (biochemical and energy content), a key biological parameter that correlates with the maintenance and growth of the organism. For this purpose, we used $A$. eigthsii as a study species, an abundant benthic bivalve with a pivotal role as a nutrient recycler (Cattaneo-Vietti et al., 2000; Lovell \& Trego, 2003; Gordillo, Malvé \& Moran, 2017). Until now, nutritional condition has been unknown in the study species and remains poorly studied in most Antarctic taxa. Specifically, our data provide evidence of spatial variation in the nutritional condition of an Antarctic bivalve at environmentally contrasting locations along the WAP. Furthermore, this study is the first to provide data about the total energy stored in this species, as an important part of the basal energy budget. Our study establishes a starting point for future experimental or in situ studies addressing how marine invertebrates may respond to climate change in the Antarctic ecosystem.

\section{Materials \& Methods}

\section{Sample collection}

To assess nutritional condition of a key benthic species among localities with contrasting environmental conditions in Antarctica, adult individuals of the bivalve mollusk $A$. eightsii were collected from three roughly equidistant sites along the WAP. Samples were collected during austral summer by SCUBA diving at 10-15 $\mathrm{m}$ depth (Fig. 1). The individuals of the O'Higgins $\left(63.3^{\circ} 19^{\prime} \mathrm{S}, 57^{\circ} 53^{\prime} \mathrm{W} ; \mathrm{n}=24\right)$ and the Rothera stations $\left(67.6^{\circ} 34^{\prime} \mathrm{S}, 68^{\circ} 07^{\prime} \mathrm{W} ; \mathrm{n}=15\right)$ were collected during January 2018 , while the individuals of the Yelcho station $\left(64.9^{\circ} 52^{\prime} \mathrm{S} 63^{\circ} 35^{\prime} \mathrm{W}\right.$; n =19) were collected during March 2017. Unfortunately, it was not logistically possible to obtain samples simultaneously from all three-study sites and the potential implications of this sampling design are discussed. After collection, all the samples were immediately preserved in $99 \%$ ethanol and maintained at $-80^{\circ} \mathrm{C}$. Then, samples were transported to the UCSC Hydrobiological Resources laboratory at Concepción, Chile and kept under the same conditions until their analysis four weeks later. The collection permits were granted by the UK Government for JR17001 and JR18003 expeditions: 31/2017 and S6-2018/01. Also, a permit was granted for collection adjacent to Rothera Research Station: 33/2017.

Recently, potentially cryptic species have been documented, suggesting two different lineages of $A$. eightsii along the WAP (González-Wevar et al., 2019). Accordingly, to avoid biases in the biological response, samples from a single lineage have been used in the present study, following genetic analyses (Muñoz-Ramírez et al., 2020).

\section{Shell length and body mass}


158 These data were obtained as previously described in Bascur et al., (2020). Using Vernier calipers

159

160

161

162

163

164

165

166

167

168

169

170

171

172

173

174

175

176

177

178

179

180

181

182

183

184

185

186

187

188

189

190

191

192

193

194

195

196

197

with $0.01 \mathrm{~mm}$ precision, we determined the individuals' sizes, measured as the distance between the anterior and posterior edges of the shell (i.e. shell length). To determine the body mass of each individual, the soft tissue was separated from the shells and washed with abundant distilled water on a $0.2 \mathrm{~mm}$ sieve in order to remove salt and sediment. Then, samples were frozen at -20 ${ }^{\circ} \mathrm{C}$ for 24 hours in independent labeled Eppendorf tubes and subsequently dried for 48 hours at $80^{\circ} \mathrm{C}$ by sublimation in a lyophilizer (FDU-7012, Operon). Finally, using an analytical balance with a sensitivity of $0.1 \mathrm{mg}$ (LA230S, SARTORIUS), body mass was determined as the dry mass of the individuals.

\section{Proximate biochemical composition (lipid and protein content)}

Following methods described in Bascur et al., (2020), the proximate composition was measured in $20 \mathrm{mg}$ of homogenized dry mass for each individual and expressed in absolute values ( $\mathrm{mg} 20$ $\mathrm{mg}^{-1}$ ), and then calculated in relative values of dry mass for each biochemical component [\% dry mass, $(\mathrm{DM})=(\mathrm{mg}$ of component $\times 100) / \mathrm{mg}$ of $\mathrm{DM}]$. In order to improve the performance of the tests, samples were exposed for 15 minutes at $6{ }^{\circ} \mathrm{C}$ in an ultrasonic bath (AC-120H, MRC) with distilled water (protein content) or dichloromethane: methanol (lipid content), and were then analyzed using the methods outlined below.

Lipid content was quantified both in the dry samples and in the ethanol in which the samples were preserved, following the gravimetric method of Folch, Lees \& Stanley (1957), modified by Cequier-Sánchez et al., (2008). Each dried sample was homogenized in amber tubes with $5 \mathrm{~mL}$ of dichloromethane: methanol (2:1). Then, samples were combined with $4 \mathrm{~mL}$ of $0.88 \%$ potassium chloride, mixed for 15 seconds in a vortex (SBS100-2, Select Vortexer) and centrifuged (S-8, Boeco) for 5 minutes at $6{ }^{\circ} \mathrm{C}$ and $1500 \mathrm{rpm}$. The precipitate of each sample was transferred to pre-weighed vials and dried through evaporation using ultrapure nitrogen gas (109A YH-1, Glass Col). Total lipid extract obtained by evaporating the solvent was weighed on a precision balance (120A, Precise) and was calculated by subtracting the weight of the empty vial from the weight of the vial with the lipid extract. A similar method was used to obtain the lipid content that potentially was released from the samples into the solvent in which they were preserved (i.e. ethanol). The ethanol from each sample was evaporated, in a previously weighed flask, through a rotary evaporator (RE-2000A, Winkler). Once the solvent has evaporated, the lipid content was obtained by subtracting the weight of the empty flask from the weight of the flask containing the lipid extract. Since we found a very small quantity of lipid in the single ethanol extracts (only $8-10 \%$ of the total individual lipid content) we decided to pool the lipid content found in each ethanol sample with the lipid content found in each individual. Finally, lipid extract of each sample was preserved at $-80{ }^{\circ} \mathrm{C}$ in dichloromethane: methanol (2:1) with butylhydroxytoluene (BHT) as an antioxidant to avoid sample degradation.

Protein content was quantified using a microplate adaptation of the BIO-RAD colorimetric assay of Lowry et al., (1951). This kit included three reagents: S (aqueous solution of sodium dodecyl sulfate), A (alkaline copper tartrate solution) and B (diluted Folin solution). The dry

Peer) reviewing PDF | (2021:08:64850:2:0:NEW 24 Nov 2021) 
198

199

200

201

202

203

204

205

206

207

208

209

210

211

212

213

214

215

216

217

218

219

220

221

222

223

224

225

226

227

228

229

230

231

232

233

234

235

236

237

samples of $4 \mathrm{mg}$ for each individual were homogenized in $200 \mu \mathrm{L}$ of ultrapure water (Mili-Q). Then, $5 \mu \mathrm{L}$ of the mixture was transferred to a 96-well microplate with $200 \mu \mathrm{L}$ of Reagent B and $25 \mu \mathrm{L}$ of Reagent $\mathrm{A}^{\prime}$ (mixture of $20 \mu \mathrm{L}$ of Reagent $\mathrm{S}$ and $1 \mathrm{~mL}$ of Reagent $\mathrm{A}$ ). Subsequently, the samples were shaken for 15 seconds in a vortex (SBS100-2, Select Vortexer) and incubated in the microplates for 15 minutes at room temperature. Finally, the absorbance was measured with a spectrophotometer at a wavelength of $750 \mathrm{~nm}$ (ELx808, Biotek). The concentration of each sample was obtained using a calibration curve for proteins, created by diluting different concentrations of bovine serum albumin (500-0111, Bio-Rad).

\section{Energy content}

The energy content $\left(\mathrm{J} 20 \mathrm{mg} \mathrm{DM}^{-1}\right)$ was estimated using a bioenergetics equivalent from the biochemical composition data (lipid and protein), as formerly described in Bascur et al., (2020). The bioenergetics equivalents were calculated through conversion coefficients: (a) $1 \mathrm{mg}$ of lipids $=39.54 \mathrm{~J}$, (b) $1 \mathrm{mg}$ of protein $=23.64 \mathrm{~J}$. An approximation of the total energy content for each individual was calculated by adding the energy equivalents of the biochemical composition (total energy = J mg lipid + J mg protein) (Winberg, 1971; Urzúa et al., 2012; Bascur et al., 2017).

\section{Fatty acid composition}

Fatty acid profile was determined through standard methods (Urzúa et al., 2011; Bascur et al., 2018; Bascur et al., 2020). Specifically, fatty acid methyl esters (FAMEs) were measured after preparation using the sample's lipid extract. Lipid extracts were esterified at $70^{\circ} \mathrm{C}$ for $1 \mathrm{~h}$ in a Thermo-Shaker (DBS-001, MRC) using sulfuric acid (1\% in methanol) incubations. Then, each sample was vortexed (SBS100-2, Select Vortexer) with $3 \mathrm{~mL}$ of n-hexane and centrifuged for 15 s. This process was repeated three times and the supernatant was transferred to labeled tubes. Finally, using a nitrogen evaporator (109A YH-1, Glass Col), fatty acids were concentrated. The measurement of FAMEs was performed using a gas chromatograph (Agilent, model 7890A) at set temperature equipped with a DB-225 column (J\&W Scientific, $30 \mathrm{~m}$ in length, 0.25 internal diameter, and $0.25 \mu \mathrm{m}$ film). Using chromatography software (Agilent ChemStation, USA), individual FAMEs were identified by comparison to known standard fatty acids of marine origin (certificate material, Supelco 37 FAME mix 47885-U (Malzahn et al., 2007; Urzúa et al., 2011). Each sample was quantified using a calibration curve for fatty acids, diluting different concentrations of Supelco 37 FAME mix standard.

\section{Statistical analysis}

Statistical analyses were performed based on standard methods (Sokal \& Rohlf, 1995; Clarke \& Gorley, 2006; Zuur, Ieno \& Graham, 2007) in the STATISTICA V8 and PRIMER V6 (+ PERMANOVA) software packages with a $95 \%$ confidence level $(p<0.05)$. The assumptions of the ANOVA analysis were evaluated with Kolmogorov-Smirnov tests for normality and Levene test for homogeneity of variances. Considering that sample sizes for each group were different, a type 3 sum of squares was used for ANOVA and PERMANOVA analyses. Besides, when 
238

239

240

241

242

243

244

245

246

247

248

249

250

251

252

253

254

255

256

257

258

259

260

261

262

263

264

265

266

267

268

269

270

271

272

273

274

275

276

277

significant differences were detected for ANOVA or Kruskal-Wallis test, post hoc Tukey HSD or multiple range tests with a Bonferroni correction were performed to assess differences among localities, respectively. All analyzes were performed with locality as a factor [with 3 levels:

O'Higgins station (northern WAP), Yelcho station (middle WAP) and Rothera station (southern WAP)].

The shell length of $A$. eightsii individuals collected at the three study localities was analyzed through a one-way ANOVA as assumptions of normally distributed data and homogeneity of variances were fulfilled. Because these assumptions (normality and homogeneity) were not fulfilled for soft tissue dry mass, lipid and protein content (mg and \%DM) and energy content of A. eightsii individuals captured at the three study localities, these variables were analyzed by non-parametric Kruskal-Wallis tests. Also, the assumptions of normality and homogeneity of variances were evaluated for the quantity of each fatty acid (e.g. C16: 0) and for the total values of each group of fatty acids (e.g. total saturated fatty acids, SFA) among the three study localities. The vast majority of fatty acid comparisons were analyzed with a Kruskal-Wallis test because they did not fulfill ANOVA assumptions. The exceptions analyzed with a one-way ANOVA after a $\log (\mathrm{x}+1)$ data transformation, were C18:0 (normality: $\mathrm{KS}=0.11, \mathrm{p}>0.20$; homogeneity: $\mathrm{F}=2.91, \mathrm{p}=0.06$ ), $\mathrm{C} 22: 6 \mathrm{n}-3$ (normality: $\mathrm{KS}=0.14, \mathrm{p}>0.20$; homogeneity: $\mathrm{F}=$ $2.50, \mathrm{p}=0.09$ ) and the total of SFA (normality: $\mathrm{KS}=0.12, \mathrm{p}>0.20$; homogeneity: $\mathrm{F}=1.89, \mathrm{p}=$ 0.16). On the other hand, the fatty acids $C 18: 2 n-6 c$ and $C 22: 1 n-9$ were only found in two localities, and as they did not fulfill the assumptions of normality and homogeneity, they were analyzed with a Mann-Whitney U test.

In addition, multivariate analyses were conducted to compare fatty acid composition. A oneway permutational multivariate analysis of variance (PERMANOVA) analysis based on BrayCurtis similarity and fourth root data transformation was performed to evaluate the complete fatty acids data set. Moreover, a similarity percentage analysis (SIMPER) was carried out to observe the percentage of contribution of each fatty acid to dissimilarity among localities. Last, a principal component analysis (PCA) based on Bray-Curtis similarity and square root data transformation was used to visualize the spatial distribution of data and the fatty acid with the highest contribution at each locality (Pearson Correlation $>0.9$ ).

\section{Results}

\section{Shell length and body mass}

Shell length (mm ind. ${ }^{-1}$ ) showed no significant differences among the three study localities (Fig. 2a, Table S1). In contrast, body mass ( $\mathrm{mg}$ ind. ${ }^{-1}$ ) was significantly different between the study localities, since individuals around O'Higgins and Yelcho stations had a higher body mass than individuals from Rothera station (Fig. 2b, Table S2).

\section{Proximate biochemical composition and energy content}

Significant variation among locations were found for lipid content (mg $20 \mathrm{mg} \mathrm{DM}^{-1}$; Fig. 3a, Table S2), lipid percentage (\% DM; Fig. 3b, Table S2), protein content (mg $20 \mathrm{mg} \mathrm{DM}^{-1}$; Fig. 
278 3c, Table S2), protein percentage (\% DM; Fig. 3d, Table S2) and energy content (J $20 \mathrm{mg} \mathrm{DM}^{-1}$; 279 Fig. 4, Table S2). In all these cases, higher values occurred at O'Higgins station compared to 280 Yelcho and Rothera stations.

281

282

283

\section{Fatty acid composition}

284 One-way ANOVA results showed some significant differences among the fatty acid profiles at

285

286

287

288

289

290

291

292

293

294

295

296

297

298

299

300

301

302

303

304

305

306

307

308

309

310

311

312

313

314

315

316

317 the three study localities. The amount of total fatty acid, saturated fatty acid, monounsaturated fatty acid, polyunsaturated fatty acid $n-6$, polyunsaturated fatty acid $n-3$, and total polyunsaturated fatty acid was higher in O'Higgins station individuals than those from Yelcho and Rothera station (Table 1).

PERMANOVA analysis, which compares the complete fatty acid profile, showed significant statistical differences among locations (Pseudo- $\mathrm{F}_{2,55}=206.68 ; \mathrm{p}<0.001 ; 9999$ permutations; Table S3). Those differences also displayed a clear separation in the spatial distribution among the three populations in the PCA plot (Fig. 5). This is consistent with the SIMPER analysis, since the contribution to the dissimilarity was driven by different fatty acids for each comparison between localities (Table 2).

\section{Discussion}

The WAP exhibits the strongest gradient in physical conditions in Antarctica and acute recent environmental change makes it an ideal place to explore and study biological responses to climate. The present study provides the first record of interpopulational variability in the nutritional condition of a marine bivalve species along the WAP. We found that individuals of $A$. eightsii showed significant differences in biochemical composition between three study localities that are likely to have consequences for the populations. Individuals collected at O'Higgins (the northernmost of our study sites) showed a higher lipid, protein, energy content, and fatty acid levels (SFA, MUFA and PUFA) than individuals collected at Yelcho and Rothera stations. The observed differences in the nutritional condition may be due to each population's ability to adjust their biochemical composition in response to the prevailing environmental conditions at each site within their broad latitudinal distribution range (Guzmán-Rivas et al., 2021).

The biochemical composition of marine invertebrates is influenced by oceanographic changes exhibited at different latitudes (Guzmán-Rivas et al., 2021). It is possible to observe clear differences of some environmental variables along the latitudinal gradient of the WAP (Rogers et al., 2020). In terms of temperature, the clearest partition is between the northern and the central/southern WAP (Cook et al., 2016). In the northern part, the inflow of water masses from the Weddell Sea can maintain ocean temperatures below $0{ }^{\circ} \mathrm{C}$ throughout most of the water column (Moffat \& Meredith, 2018). Further south, ocean temperature is dominated by diverse factors (e.g. glacial melt) that result in a water column that is particularly warm at depth $\left(1^{\circ} \mathrm{C}\right.$ or higher), capped by a thin, transient, warm layer in summer (Cook et al., 2016). Also, there is significant spatial structure in oceanic primary productivity along the WAP, reflecting combined physical and biogeochemical drivers that include water column structure, upwelling and sea ice 
318

319

320

321

322

323

324

325

326

327

328

329

330

331

332

333

334

335

336

337

338

339

340

341

342

343

344

345

346

347

348

349

350

351

352

353

354

355

356

357

seasonality (see Rogers et al., 2020). Marked meridional contrasts are evident during summer, as higher concentrations of chlorophyll-a are present during December-March in the south, while the bloom in northern WAP is more limited to the period December-February (Montes-Hugo et al., 2009; Kim et al., 2018). This regional variability is driven by local environmental settings (Kavanaugh et al., 2015). We suggest that our study species would be likely to present intraspecific variability in nutritional characteristics along the WAP, driven by the environmental gradient and contrasting oceanographic parameters. Such differences could be intensified by the contrasting effects of climate change on marine ecosystems along the WAP (Cook et al., 2016). For this reason, future studies should assess the potential local adaptation of its populations (Sanford \& Kelly, 2011; Segovia et al., 2020).

Food available in Antarctic sediments, consumed by detritivoral taxa, contains an important source of organic matter from both planktonic and benthic origin (Glover et al., 2008; Minks et al., 2008). Nevertheless, the amount of this food is not stable, since spatio-temporal variations have been observed in the amount of food available in Antarctic sediment (Isla et al., 2011), which can be correlated to both ambient light levels in the shallows and the supply of detritus to the sea floor. For instance, sediments with a higher content of lipids and proteins (high food quality) were recorded during the autumn and sediments with a higher content of carbohydrates (low food quality) during spring (Isla et al., 2011). Moreover, recent spatial variability in total organic carbon (TOC), as a proxy of food quantity, was found in sediment along a distance gradient from a WAP deglaciating fjord (Kim et al., 2021). There was a higher proportion of TOC at more distant sites than at those closer to the glacier front (Kim et al., 2021). These TOC results are consistent with previous results of the nutritional condition of the bivalve Nuculana inequisculpta at different distances from the glacier in the same Antarctic fjord (Bascur et al., 2020). This research found that individuals captured at the site closest (ca. $670 \mathrm{~m}$ ) to the glacier front had a poorer nutritional condition, with lower lipid and protein content, than individuals captured at the site further (ca. $2700 \mathrm{~m}$ ) from the glacier edge (Bascur et al., 2020). In this context, spatial changes in the food quality and quantity available to $A$. eightsii could be expected due to the environmental gradient along the WAP. This is a factor that could explain the high variability we found between populations from different geographical regions.

Recently, the reproductive cycle and ontogenetic growth rhythms of $A$. eightsii have been studied at the WAP (Román-Gonzalez et al., 2017; Lau et al., 2018). These studies point out that this bivalve can exhibit different growth patterns depending on the allocation of energy resources. This suggests that even some coexisting individuals could be in different stages of their gametogenesis or somatic growth cycle (asynchronous growth). Based on this, it could be hypothesized that our Rothera population, with its lower energy content (Fig. 4), is allocating energy towards somatic growth while the O'Higgins and Yelcho populations, with their higher tissue energy content (Fig. 4), could be allocating more energy to gonad growth. Therefore, based on nutritional condition analysis, the different populations within our study, could present asynchronous ecological characteristics in terms of reproduction, recruitment, and somatic growth along the WAP (Steinberg, 2018). Nevertheless, more studies on growth phenology of

Peer] reviewing PDF | (2021:08:64850:2:0:NEW 24 Nov 2021) 
358

359

360

361

362

363

364

365

366

367

368

369

370

371

372

373

374

375

376

377

378

379

380

381

382

383

384

385

386

387

388

389

390

391

392

393

394

395

396

397

different populations of this species along the WAP are necessary in order to support this argument.

Within lipid composition, fatty acids have a pivotal role in the membrane function, nervous system development (Beltz et al., 2007), immune response (Bell et al., 2006; Fritsche, 2006), gonadal maturation (Hurtado et al., 2012; Bolognini et al., 2017), growth (Marshall, McKinley \& Pearce, 2010) and as energy sources in long-term starvation conditions (Auerswald et al., 2015). It is thought that most mollusks, including bivalves, lack the capacity to biosynthesize n-3 and n6 PUFA de novo (Zhukova, 2019). That is, fatty acids such as EPA (eicosapentaenoic acid: C20: $5 n-3$ ) and DHA (docosahexaenoic acid: $\mathrm{C} 22: 6 n-3$ ) are obtained exclusively through food. In this context, A. eightsii individuals from O'Higgins station had a higher quantity of total fatty acids (especially PUFA as EPA and DHA) than individuals collected at Yelcho and Rothera stations, likely influenced by different food quantity or quality, either in sediment or from phytoplankton (Montes-Hugo et al., 2009; Schofield et al., 2017). Fatty acids can be used as biomarkers of trophic relationships (e.g. see Hughes et al., 2005). Fatty acid markers have proved highly successful in assessing the trophic ecology of Antarctic marine species (e.g. Yang et al., 2016; Servetto et al., 2017; Rossi et al., 2018). Considering the fatty acid profiles found in the present study and the use of fatty acid biomarkers available in the literature, we suggest that $A$. eightsii has an omnivorous feeding behavior, mainly consuming flagellates, detritus, different types of algae and meiofauna (Table 3). On the other hand, one remarkable result is that individuals at Yelcho had higher levels of detritus biomarkers (C22:0 and C18:1n-9), while individuals at O'Higgins had higher levels of microalgae markers such as diatoms and dinoflagellates (C20:5n3 and C16:0) (Table 3). While the composition of the phytoplankton species within the bloom is relatively consistent across the WAP, there is up to a 5 fold variation in integrated water column chlorophyll-a from year to year (Schofield et al., 2017). The nature of the bloom is strongly associated with sea ice and is expected to be impacted by ocean warming (Deppeler \& Davidson, 2017). In this respect, A. eightsii are well suited for this variability in food supply as they are known to switch between filter and deposit feeding, depending on the availability of phytoplankton, a strategy that has been linked to their continuous oogenesis around Rothera Point (Lau et al., 2018). Such fatty acid and diet profiles represent a valuable contribution to baselines for future studies on WAP marine food webs.

\section{Limitations and future directions}

The absence of information on gonadal maturation or development of the analyzed individuals is considered an important limitation in this study. Our samples were collected in summer, temporally distinct from the spawning season described for A. eightsii in the southern WAP as during winter (Lau et al., 2018). This suggests gonad maturation would form a minor (if any) component of the variation between locations, especially since we are comparing a quite narrow biogeographic range. However, it is necessary to take into account that there could be spatial variation of the reproductive period in this species at different locations in the WAP. In this context, continuous reproductive analysis (i.e. gonadal maturation) using $A$. eightsii at a number

Peer) reviewing PDF | (2021:08:64850:2:0:NEW 24 Nov 2021) 
398

399

400

401

402

403

404

405

406

407

408

409

410

411

412

413

414

415

416

417

418

419

420

421

422

423

424

425

426

427

428

429

430

431

432

433

434

435

436

437

of sites along the WAP environmental gradient should be conducted in future studies, since there is a generalized lack of information on this topic within Antarctic marine invertebrates.

Ideally, future studies should also consider the collection of environmental parameters (e.g. seawater temperature, salinity, etc.) in order to evaluate any potential relationship between biological and environmental data. There are few research centers along the WAP with the capacity to obtain long-term environmental data (e.g. Carlini, Palmer, Rothera). Unfortunately, in the case of the Chilean bases O'Higgins and Yelcho, there are no oceanographic monitoring programs and data could not be taken by other means. For this reason, it was not possible in our study to include environmental data to provide an overall picture at the three study sites. In this context, we emphasize the urgent need to obtain long-term oceanographic data in the northern WAP. In this way, a more representative monitoring of the effect of regional warming on the WAP should improve our understanding of the impacts of climate change on the biology of Antarctic marine invertebrates.

Another consideration is that Yelcho samples were collected eight months earlier than O'Higgins and Rothera samples due to logistical difficulties related to working in isolated and strongly seasonal ecosystems with limited access. This region may experience significant interannual variability, driven by the Southern Annular Mode (SAM) and El Niño-Southern Oscillation (ENSO) (Martinson et al., 2008; Santamaría-del-Ángel et al., 2021), which can translate into biotic variability. In this context, the oceanographic variables such as temperature and salinity at the southern area of Anvers Island (where Yelcho is located) indicated only limited (but significant) interannual variation between the summer seasons of 2017 and 2018 (Fig. S1). On the contrary, chlorophyll-a did not display significant differences between summer seasons of 2017 and 2018 (Fig. S1). Those differences, especially in temperature between the two years at Yelcho, while not being lethal to adults, could influence metabolism (e.g. Davenport, 1988b) and therefore the balance between energy gains and costs, modifying energy storage and growth (e.g. Morley et al., 2016). Furthermore, temperature can alter the composition of phytoplankton communities (Schofield et al., 2017) and the nutritional properties of the organic matter stored in the sediment (e.g. Malinverno \& Martínez, 2015), causing a change in the type of food available for benthic species. In turn, this limitation also makes it difficult to relate biological aspects to environmental variability, given the lack of information on precise gonadal cycle of Antarctic species. Therefore, differences found in our study might not only be driven by spatial variability, but also by a mixed spatio-temporal variability that should be carefully considered in futures studies.

A final limitation is that we did not analyze glycogen content, even though it is an important body component of bivalves. Glycogen is used mainly as an energy source for oocyte production within the gonads (Mathieu \& Lubet, 1993). Thus, by analyzing this component, we would have had insights into the stage of gonadal maturation (e.g. mature or immature stage) of individuals. In this context, despite the fact that proteins, lipids and fatty acids are also an important part of the biochemical composition of organisms, we suggest that related future studies prioritize the evaluation of glycogen content and its relationship with the reproductive cycle of $A$. eightisii. 
438

439

440

441

442

443

444

445

446

447

448

449

450

451

452

453

454

455

456

457

458

459

460

461

462

463

464

465

466

467

468

469

470

471

472

473

474

475

476

477

In spite of limitations mentioned above, the biochemical and energetic results shown here are within previously published ranges for Antarctic marine invertebrates (Heine et al., 1991; McClintock et al., 1991; McClintock et al., 1992). There is also agreement with the predominance of protein content above lipid content, which in our case was almost three times as much protein (13.11-22.34\% DM) as lipid (4.60-8.30\% DM). Furthermore, differences were found between the O'Higgins and Rothera samples even though they were captured on exactly the same date. Only the Yelcho data should be interpreted with caution due to the difference in the date of collection, which could potentially be affected by interannual environmental differences. Therefore, we suggest that our study represents a valuable first step, highlighting the importance of evaluating the relationship between physiological and regional oceanographic processes, influencing the nutritional condition of benthic marine invertebrates along the WAP. This will add spatial context to high resolution temporal sampling that is currently undertaken at Rothera (Lau et al., 2018). Additional testing with other taxa and a more comprehensive spatial distribution of study sites can evaluate whether $A$. eightsii proves to be a good example of how biochemistry of Antarctic marine invertebrates responds to changes in environmental conditions.

\section{Conclusions}

The current study provides novel and valuable information on large-scale spatial variation in the biochemical composition and energy content, as a proxy of nutritional condition, of three populations of the bivalve mollusk $A$. eightsii at the WAP. We observed that the northern population (O'Higgins) had the highest nutritional condition (higher content of lipids, proteins, energy and fatty acids), followed by the middle population (Yelcho), and finally the southern population of the WAP (Rothera) with the poorer nutritional condition (lower content of lipids, proteins, energy and fatty acids). Furthermore, differences regarding feeding biomarkers were also observed between sites with Yelcho individuals having higher levels of detritus biomarkers (C22: 0 and C18: 1n-9), and O'Higgins individuals having higher levels of microalgae markers. It seems likely that this spatial variability is driven either by different innate growth rhythms of populations or by contrasting environmental conditions (e.g. temperature and food availability) at each study site at the WAP.

\section{Acknowledgements}

We thank the divers that collected samples at O'Higgins, Yelcho and Rothera stations. Special thanks to Sara García-Ravelo for her valuable input with the English proof-reading and general improvement of this manuscript. Constructive reviews from K. Liversage and other two anonymous reviewers considerably improved this publication.

\section{References}


478

479

480

481

482

483

484

485

486

487

488

489

490

491

492

493

494

495

496

497

498

499

500

501

502

503

504

505

506

507

508

509

510

511

512

513

514

515

516

Ahn I, Surh J, Park Y-G, Kwon H, Choi K-S, Kang S-H, Choi HJ, Kim KW, Chung H. 2003. Growth and seasonal energetics of the Antarctic bivalve Laternula elliptica from King George Island, Antarctica. Marine Ecology Progress Series 257:99-110 DOI: 10.3354/meps257099. Auerswald L, Meyer B, Teschke M, Hagen W, Kawaguchi S. 2015. Physiological response of adult Antarctic krill, Euphausia superba, to long-term starvation. Polar Biology 38:763-780 DOI: $10.1007 / \mathrm{s} 00300-014-1638-\mathrm{z}$.

Barnes DKA, Sands CJ, Cook A, Howard F, Román-González A, Muñoz-Ramirez C, Retallick K, Scourse J, Van Landeghem K, Zwerschke N. 2020. Blue carbon gains from glacial retreat along Antarctic fjords: What should we expect? Global Change Biology 26:2750-2755 DOI: $10.1111 / \mathrm{gcb} .15055$.

Bascur M, Guzmán F, Mora S, Urzúa Á. 2017. Seasonal changes in the biochemical composition of females and offspring of red squat lobster, Pleuroncodes monodon (Decapoda, Munididae) from the Southeastern Pacific. Marine Ecology 38:e12419 DOI: 10.1111/maec.12419.

Bascur M, Guzmán F, Mora S, Espinoza P, Urzúa Á. 2018. Temporal variation in the fatty acid composition of ovigerous females and embryos of the squat lobster Pleuroncodes monodon (Decapoda, Munididae). Journal of the Marine Biological Association of the United Kingdom 98:1977-1990 DOI: 10.1017/S002531541700145X.

Bascur M, Muñoz-Ramírez C, Román-González A, Sheen K, Barnes DKA, Sands CJ, Brante A, Urzúa Á. 2020. The influence of glacial melt and retreat on the nutritional condition of the bivalve Nuculana inaequisculpta (Protobranchia: Nuculanidae) in the West Antarctic Peninsula. PLoS ONE 15:e0233513 DOI: 10.1371/journal.pone.0233513.

Bell JG, Strachan F, Good JE, Tocher DR. 2006. Effect of dietary echium oil on growth, fatty acid composition and metabolism, gill prostaglandin production and macrophage activity in Atlantic cod (Gadus morhua L.). Aquaculture Research 37:606-617 DOI: 10.1111/j.13652109.2006.01470.x.

Beltz B, Tlusty M, Benton J, Sandeman D. 2007. Omega-3 fatty acids upregulate adult neurogenesis. Neuroscience Letters 415:154-158 DOI: 10.1016/j.neulet.2007.01.010.

Bolognini L, Donato F, Lucchetti A, Olivotto I, Truzzi C, Randazzo B, Antonucci M, Illuminati S, Grati F. 2017. A multidisciplinary approach to study the reproductive biology of wild prawns. Scientific Reports 7:16781 DOI: 10.1038/s41598-017-16894-1.

Cañavate JP. 2018. Advancing assessment of marine phytoplankton community structure and nutritional value from fatty acid profiles of cultured microalgae. Reviews in Aquaculture 11:527-549 DOI: 10.1111/raq.12244.

Cattaneo-Vietti R, Chiantore M, Schiaparelli S, Albertelli G. 2000. Shallow- and deep-water mollusc distribution at Terra Nova Bay (Ross Sea, Antarctica). Polar Biology 23:173-182 DOI: $10.1007 / \mathrm{s} 003000050024$.

Cequier-Sánchez E, Rodríguez C, Ravelo A, Zárate R. 2008. Dichloromethane as a solvent for lipid extraction and assessment of lipid classes and fatty acids from samples of different natures. Journal of Agricultural and Food Chemistry 56:4297-4303 DOI: 10.1021/jf073471e. 
517 Clarke KR, Gorley RN. 2006. PRIMER v6: User Manual/Tutorial (Plymouth Routines in 518 Multivariate Ecological Research). Plymouth: PRIMER-E.

519 Cook AJ, Holland PR, Meredith MP, Murray T, Luckman A, Vaughan DG. 2016. Ocean forcing 520 of glacier retreat in the western Antarctic Peninsula. Science 353:283-286 DOI:

$521 \quad 10.1023 / \mathrm{A}: 1026021217991$.

522 Dalsgaard J, John MS, Kattner G, Müller-Navarra D, Hagen W. 2003. Fatty acid trophic markers

523

524

525

526

527

528

529

530

531

532

533

534

535

536

537

538

539

540

541

542

543

544

545

546

547

548

549

550

551

552

553

554

555 in the pelagic marine environment. Advances in Marine Biology 46:225-340 DOI: 10.1016/S0065-2881(03)46005-7.

Darriba S, Juan FS, Guerra A. 2005. Energy storage and utilization in relation to the reproductive cycle in the razor clam Ensis arcuatus (Jeffreys, 1865). ICES Journal of Marine Science 62:886-896 DOI: 10.1016/j.icesjms.2005.02.010.

Davenport J. 1988. The feeding mechanism of Yoldia (= Aequiyoldia) eightsi (Courthouy). Proceedings of the Royal Society B: Biological Sciences 232:431-442 DOI: 10.2307/36327.

Davenport J. 1988b. Oxygen consumption and ventilation rate at low temperatures in the Antarctic Protobranch bivalve mollusc Yoldia (=Aequiyoldia) eightsi (Courthouy). Comparative Biochemistry and Physiology A: Physiology 90:511-513 DOI: 10.1016/03009629(88)90228-9.

Dell RK. 1990. Antarctic Mollusca. Bulletin of the Royal Society of New Zealand 27:1-311.

Deppeler SL, Davidson AT. 2017. Southern Ocean Phytoplankton in a Changing Climate. Frontiers in Marine Science 4:40 DOI: 10.3389/fmars.2017.00040.

Folch J, Lees M, Stanley S. 1957. A simple method for the isolation and purification of total lipids from animal tissues. Journal of Biological Chemistry 276:497-509.

Fritsche K. 2006. Fatty acids as modulators of the immune response. Annual Review of Nutrition 26:45-73 DOI: 10.1146/annurev.nutr.25.050304.092610.

González-Wevar C, Gérard K, Rosenfeld S, Saucède T, Naretto J, Díaz A, Morley S, Brickle P, Poulin E. 2019. Cryptic speciation in Southern Ocean Aequiyoldia eightsii (Jay, 1839): MioPliocene trans Drake separation and diversification. Progress in Oceanography 174:44-54 DOI: 10.1016/j.pocean.2018.09.004.

González-Wevar CA, Díaz A, Gerard K, Cañete JI, Poulin E. 2012. Divergence time estimations and contrasting patterns of genetic diversity between Antarctic and southern South America benthic invertebrates. Revista Chilena de Historia Natural 85:445-456 DOI: 10.4067/S0716$078 X 2012000400007$.

Gordillo S, Malvé M, Moran G. 2017. Benthic mollusc assemblages in West Antarctica: taxa composition and ecological insights. Marine and Freshwater Research 68:2095-2105 DOI: 10.1071/MF16349.

Guzmán-Rivas F, Quispe-Machaca M, Queirolo D, Ahumada M, Urzúa Á. 2021. Latitudinal changes in the lipid content and fatty acid profiles of juvenile female red squat lobsters (Pleuroncodes monodon) in breeding areas of the Humboldt Current System. PLoS ONE 16(6):e0253314 DOI: 10.1371/journal.pone.0253314. 
556 Heine JN, McClintock JB, Slattery M, Weston J. 1991. Energetic composition, biomass, and

557

558

559

560

561

562

563

564

565

566

567

568

569

570

571

572

573

574

575

576

577

578

579

580

581

582

583

584

585

586

587

588

589

590

591

592

593

594

595

chemical defense in the common Antarctic nemertean Parborlasia corrugatus Mclntosh. Journal of Experimental Marine Biology and Ecology 153:15-25 DOI: 10.1016/S00220981(05)80003-6.

Henley SF, Schofield OM, Hendry KR, Schloss IR, Steinberg DK, Moffat C, Peck LS, Costa DP, Bakker DCE, Hughes C, Rozema PD, Ducklow HW, Abele D, Stefels J, Van Leeuwe MA, Brussaard CPD, Buma AGJ, Kohut J, Sahade R, Friedlaender AS, Stammerjohn SE, Venables HJ, Meredith MP. 2019. Variability and change in the west Antarctic Peninsula marine system: research priorities and opportunities. Progress in Oceanography 173:208-237 DOI: 10.1016/j.pocean.2019.03.003.

Hughes A, Catarino AI, Kelly M, Barnes DKA, Black K. 2005. Gonad fatty acids and trophic interactions of the echinoid Psammechinus miliaris. Marine Ecology Progress Series 5:10111 DOI: 10.3354/meps305101.

Hurtado MA, Racotta IS, Arcos F, Morales-Bojórquez E, Moal J, Soudant PH, Palacios E. 2012. Seasonal variations of biochemical, pigment, fatty acid, and sterol compositions in female Crassostrea corteziensis oysters in relation to the reproductive cycle. Comparative Biochemistry and Physiology B: Biochemistry and Molecular Biology 163:172-183 DOI: 10.1016/j.cbpb.2012.05.011.

Kavanaugh MT, Abdala FN, Ducklow H, Glover D, Fraser W, Martinson D, Stammerjohn S, Schofield O, Doney SC. 2015. Effect of continental shelf canyons on phytoplankton biomass and community composition along the western Antarctic Peninsula. Marine Ecology Progress Series 524:11-26 DOI: 10.3354/meps 11189.

Kelly JR, Scheibling RE. 2012. Fatty acids as dietary tracers in benthic food webs. Marine Ecology Progress Series 446:1-22 DOI: 10.3354/meps09559.

Kim H, Ducklow HW, Abele D, Barlett EMR, Buma AGJ, Meredith MP, Rozema PD, Schofield OM, Venables HJ, Schloss IR. Inter-decadal variability of phytoplankton biomass along the coastal West Antarctic Peninsula. Philosophical Transaction of the Royal Society AMathematical, Physical and Engineering Science 376:20170174 DOI:

$$
\text { 10.1098/rsta.2017.0174. }
$$

Lah AR, Smith J, Savins D, Dowell A, Bucher D, Benkendorff K. 2017. Investigation of nutritional properties of three species of marine turban snails for human consumption. Food Science and Nutrition 5:14-30 DOI: 10.1002/fsn3.360.

Lau SCY, Grange LJ, Peck LS, Reed AJ. 2018. The reproductive ecology of the Antarctic bivalve Aequiyoldia eightsii (Protobranchia: Sareptidae) follows neither Antarctic nor taxonomic patterns. Polar Biology 41:1693-1706 DOI: 10.1007/s00300-018-2309-2.

Legeżyńska J, Kędra M, Walkusz W. 2014. Identifying trophic relationships within the high arctic benthic community: how much can fatty acids tell? Marine Biology 161:821-836 DOI: 10.1007/s00227-013-2380-8.

Li Q, Yang L, Ke Q, Kong L. 2011. Gametogenic cycle and biochemical composition of the clam Mactra chinensis (Mollusca: Bivalvia): implications for aquaculture and wild stock 
596

597

598

599

600

601

602

603

604

605

606

607

608

609

610

611

612

613

614

615

616

617

618

619

620

621

622

623

624

625

626

627

628

629

630

631

632

633

634

635

management. Marine Biology Research 7:407-415 DOI:

10.1080/17451000.2010.515686.Lorenzo RA, Tomac A, Tapella F, Yeannes MI, Romero MC. 2021. Biochemical and quality parameters of southern king crab meat after transport simulation and re-immersion. Food Control 119:107480 DOI:

10.1016/j.foodcont.2020.107480.

Lovell LL, Trego KD. 2003. The epibenthic megafaunal and benthic infaunal invertebrates of Port Foster, Deception Island (South Shetland Islands, Antarctica). Deep-Sea Research Part II 50:1799-1819 DOI: 10.1016/S0967-0645(03)00087-0.

Lowry D, Rosenberg N, Farr A, Randall R. 1951. Protein measurement with the Folin phenol reagent. Journal of Biological Chemistry 193:265-275.

Malinverno A, Martinez E. 2015. The effect of temperature on organic carbon degradation in marine sediments. Scientific Reports 5:17861 DOI: 10.1038/srep17861.

Malzahn AM, Aberle N, Clemmesen C, Boersma M. 2007. Nutrient limitation of primary producers affects planktivorous fish condition. Limnology and Oceanography 52:2062-2071 DOI: $10.4319 / 10.2007 .52 .5 .2062$.

Marshall R, McKinley S, Pearce CM. 2010. Effects of nutrition on larval growth and survival in bivalves. Reviews in Aquaculture 2:33-55 DOI: 10.1111/j.1753-5131.2010.01022.x.

Mathieu M, Lubet P. 1993. Storage tissue metabolism and reproduction in marine bivalves - a brief review. Invertebrate Reproduction and Development 23:123-129 DOI: 10.1080/07924259.1993.9672303.

McClintock JB, Heine J, Slattery M, Weston J. 1991. Biochemical and energetic composition, population biology, and chemical defense of the antarctic ascidian Cnemidocarpa verrucosa Lesson. Journal of Experimental Marine Biology and Ecology 147:163-175 DOI: 10.1016/0022-0981(91)90180-5.

McClintock JB, Slattery M, Heine J, Weston J. 1992. Chemical defense, biochemical composition and energy content of three shallow-water Antarctic gastropods. Polar Biology 11:623-629 DOI: 10.1007/BF00237957.

Moffat C, Meredith M. 2018. Shelf-ocean exchange and hydrography west of the Antarctic Peninsula: A review. Philosophical Transaction of the Royal Society A-Mathematical, Physical and Engineering Science 376:20170164 DOI: 10.1098/rsta.2017.0164.

Montes-Hugo M, Doney SC, Ducklow HW, Fraser W, Martinson D, Stammerjohn SE, Schofield O. 2009. Recent changes in phytoplankton communities associated with rapid regional climate change along the Western Antarctic Peninsula. Science 323:1470-1473. DOI: 10.1126/science. 1164533 .

Morley SA, Suckling CS, Clark MS, Cross EL, Peck LS. 2016. Long term effects of altered pH and temperature on the feeding energetics of the Antarctic sea urchin, Sterechinus neumayeri. Biodiversity 17:34-45 DOI: 10.1080/14888386.2016.1174956.

Morley SA, Abele D, Barnes DKA, Cárdenas CA, Cotté C, Gutt J, Henley SF, Höfer J, Hughes KA, Martin SM, Moffat C, Raphael M, Stammerjohn SE, Suckling CC, Tulloch VJD, Waller CL, Constable AJ. 2020. Global Drivers on Southern Ocean Ecosystems: Changing Physical 
636

637

638

639

640

641

642

643

644

645

646

647

648

649

650

651

652

653

654

655

656

657

658

659

660

661

662

663

664

665

666

667

668

669

670

671

672

673

674

Environments and Anthropogenic Pressures in an Earth System. Frontiers in Marine Science 7:547188. DOI: 10.3389/fmars.2020.547188.

Muñoz-Ramírez C, Sands CJ, Barnes DKA, Scourse J, Roman-Gonzalez A, Morley SA, Cardenas L, Brante A. 2020. Gene flow in the Antarctic bivalve Aequiyoldia eighitsi suggest a role for the Antarctic Peninsula Coastal Current in larval dispersal. Royal Society Open Science 7:200603 DOI: 10.1098/rsos.200603.

Muñoz-Ramírez CP, Beltrán-Concha M, Pérez-Araneda K, Sands C, Barnes DKA, RománGonzález A, De Lecea A, Retallick K, Van Landeghem K, Sheen K, Gonnelli K, Scourse J, Bascur M, Brante A. In Press. Genetic variation in the small bivalve Nuculana inaequisculpta along a retreating glacier fjord, King George Island, Antarctica. Revista de Biología Marina y Oceanografía.

Ngo TTT, Kang SG, Kang DH, Sorgeloos P, Choi KS. 2006. Effect of culture depth on the proximate composition and reproduction of the Pacific oyster, Crassostrea gigas from Gosung Bay, Korea. Aquaculture 253:712-720 DOI: 10.1016/j.aquaculture.2005.09.009.

Nolan CP, Clarke A. 1993. Growth in the bivalve Yoldia eightsi at Signy Island, Antarctica, determined from internal shell increments and calcium-45 incorporation. Marine Biology 117:243-250 DOI: 10.1007/BF00345669.

Peck LS, Bullough LW. 1993. Growth and population structure in the infaunal bivalve Yoldia eightsi in relation to iceberg activity at Signy Island, Antarctica. Marine Biology 117:235241 DOI: 10.1007/BF00345668.

Peck LS, Colman JG, Murray AWA. 2000. Growth and tissue mass cycles in the infaunal bivalve Yoldia eightsi at Signy Island, Antarctica. Polar Biology 23:420-428 DOI: $10.1007 / \mathrm{s} 003000050463$.

Pogoda B, Buck BH, Saborowski R, Hagen W. 2013. Biochemical and elemental composition of the offshore-cultivated oysters Ostrea edulis and Crassostrea gigas. Aquaculture 401:53-60 DOI: 10.1016/j.aquaculture.2013.02.031.

Rogers AD, Frinault BAV, Barnes DKA, Bindoff NL, Downie R, Ducklow HW, Friedlaender AS, Hart T, Hill SL, Hofmann EE, Linse K, McMahon CR, Murphy EJ, Pakhomov EA, Reygondeau G, Staniland IJ, Wolf-Gladrow DA, Wright RM. 2020. Antarctic Futures: An Assessment of Climate-Driven Changes in Ecosystem Structure, Function, and Service Provisioning in the Southern Ocean. Annual Review of Marine Science 12:87-120 DOI: 10.1146/annurev-marine-010419-011028.

Román-González A, Scourse JD, Butler PG, Raynolds DJ, Richardson CA, Peck LS, Brey T, Hall IR. 2017. Analysis of ontogenetic growth trends in two marine Antarctic bivalves Yoldia eightsi and Laternula elliptica: implications for sclerochronology. Palaeogeography, Palaeoclimatology, Palaeoecology 465:300-306 DOI: 10.1016/j.palaeo.2016.05.004.

Rossi S, Elias-Piera F. 2018. Trophic ecology of three echinoderms in deep waters of the Weddell Sea (Antarctica). Marine Ecology Progress Series 596:143-153 DOI: $10.3354 /$ meps 12544 . 
675 Sanford E, Kelly MW. 2011. Local adaptation in marine invertebrates. Annual Review of Marine

676

677

678

679

680

681

682

683

684

685

686

687

688

689

690

691

692

693

694

695

696

697

698

699

700

701

702

703

704

705

706

707

708

709

710

711

712

713

Science 3:509-35 DOI: 10.1146/annurev-marine-120709-142756.

Schofield O, Saba G, Coleman K, Carvalho F, Couto N, Ducklow H, Finkel Z, Irwin A, Kahla A, Miles T, Montes-Hugo M, Stammerjohn S, Waite N. 2017. Decadal variability in coastal phytoplankton community composition in a changing West Antarctic Peninsula. Deep-Sea Research Part I 124:42-54 DOI: 10.1016/j.dsr.2017.04.014.

Segovia NI, González-Wevar CA, Haye PA. 2020. Signatures of local adaptation in the spatial genetic structure of the ascidian Pyura chilensis along the southeast Pacific coast. Scientific Reports 10:14098 DOI: 10.1038/s41598-020-70798-1.

Servetto N, Rossi S, Fuentes V, Alurralde G, Lagger C, Sahade R. 2017. Seasonal trophic ecology of the dominant Antarctic coral Malacobelemnon daytoni (Octocorallia, Pennatulacea, Kophobelemnidae). Marine Environmental Research 130:264-274 DOI: 10.1016/j.marenvres.2017.08.003.

Sokal RR, Rohlf FJ. 1995. Biometry. The principles and practice of statistics in Biological Research. New York: W.H. Freeman.

Somero GN, Lockwood BL, Tomanek L. 2017. Biochemical adaptation: response to environmental challenges from life's origins to the anthropocene. Sunderland: Sinauer Associates.

Steinberg CEW. 2018. Aquatic animal nutrition: A mechanistic perspective from individuals to generations. Switzerland: Springer.

Tacon AGJ, Metian M. 2013. Fish matters: importance of aquatic foods in human nutrition and global food supply. Reviews in Fisheries Science 21:22-38 DOI: 10.1080/10641262.2012.753405.

Tan K, Zhang H, Li S, Ma H, Zheng H. 2021. Lipid nutritional quality of marine and freshwater bivalves and their aquaculture potential. Critical Reviews in Food Science and Nutrition DOI: 10.1080/10408398.2021.1909531.

Urzúa Á, Anger K. 2011. Larval biomass and chemical composition at hatching in two geographically isolated clades of the shrimp Macrobrachium amazonicum: intra or interspecific variation? Invertebrate, Reproduction and Development 55:236-246 DOI: 10.1080/07924259.2011.576155.

Urzúa Á, Paschke K, Gebauer P, Anger K. 2012. Seasonal and interannual variations in size, biomass and chemical composition of the eggs of North Sea shrimp, Crangon crangon (Decapoda: Caridea). Marine Biology 159:583-599 DOI: 10.1007/s00227-011-1837-x.

Vesterinen J, Keva O, Kahilainen KK, Strandberg U, Hiltunen M, Kankaala P, Taipale SJ. 2020. Nutritional quality of littoral macroinvertebrates and pelagic zooplankton in subarctic lakes. Limnology and Oceanography 66:S81-S97 DOI: 10.1002/lno.11563.

Volkman J, Barrett S, Blackburn S, Mansour M, Sikes E, Gelin F. 1998. Microalgal biomarkers: a review of recent research developments. Organic Geochemistry 29:1163-1179 DOI: 10.1016/S0146-6380(98)00062-X. 
714 Winberg GG. 1971. Methods for the estimation of production of aquatic animals. London:

715 Academic Press.

716 Yang G, Li CL, Guilini K, Peng QC, Wang YQ, Zhang Y, Zhang Y. 2016. Feeding strategies of

717 four dominant copepod species in Prydz Bay, Antarctica: Insights from a combined fatty acid

718 biomarker and stable isotopic approach. Deep-Sea Research Part I 114:55-63 DOI:

$719 \quad 10.1016 /$ j.dsr.2016.04.016.

720 Zardus JD. 2002. Protobranch bivalves. Advances in Marine Biology 42:1-65 DOI:

$721 \quad 10.1016 / \mathrm{s} 0065-2881(02) 42012-3$.

722 Zhukova NV. 2019. Fatty acids of marine mollusks: Impact of diet, bacterial symbiosis and

723 biosynthetic potential. Biomolecules 9:857 DOI: 10.3390/biom9120857.

724 Zuur AF, Ieno EN, Graham SM. 2007. Analysing ecological data (Statistics for Biology and 725 Health). New York: Springer.

726 Zwerschke N, Sands CJ, Roman-Gonzalez A, Barnes DKA, Guzzi A, Jenkins S, Muñoz-Ramírez 727 C, Scourse J. 2021. Quantification of blue carbon pathways contributing to negative feedback 728 on climate change following glacier retreat in West Antarctic fjords. Global Change Biology 729 DOI: $10.1111 / \mathrm{gcb} .15898$. 


\section{Table $\mathbf{1}$ (on next page)}

Fatty acid composition (expressed in mg of fatty acid g dry mass ${ }^{-1}$ and in $\%$ of total FA pool in parentheses) of the soft tissue of $A$. eightsii collected in three different localities of Western Antarctica Peninsula. Values represent

Different letters in the superscript of each fatty acid (FA) indicate significant differences among localities ( $p<0.05$; parametric post-hoc Tukey HSD or non-parametric multiple range tests). Stat. value represent the statistical value obtained in each analysis (F of ANOVA for C18:0, C22:6n-3 and total SFA; U of Mann-Whitney for C18:2n-6c and C22:1n-9; H of KruskalWallis for all the other comparisons). 
1 Table 1. Fatty acid composition (expressed in $\mathrm{mg}^{\circ}$ f fatty acid $\mathrm{g} \mathrm{dry} \mathrm{mass}^{-1}$ and in \% of total FA 2 pool in parentheses) of the soft tissue of $A$. eightsii collected in three different localities of Western 3 Antarctica Peninsula. Values represent mean $\pm \mathbf{S D}, \mathbf{n}=\mathbf{5 8}$. Different letters in the superscript of each 4 fatty acid (FA) indicate significant differences among localities $(p<0.05$; parametric post-hoc Tukey 5 HSD or non-parametric multiple range tests). Stat. value represent the statistical value obtained in each 6 analysis (F of ANOVA for C18:0, C22:6n-3 and total SFA; U of Mann-Whitney for C18:2n-6c and 7 C22:1n-9; $\mathrm{H}$ of Kruskal-Wallis for all the other comparisons).

\begin{tabular}{|c|c|c|c|c|c|}
\hline \multicolumn{6}{|c|}{ Locality } \\
\hline Fatty acid & O'Higgins $\left(63^{\circ} \mathrm{S}\right)$ & Yelcho $\left(64^{\circ} \mathrm{S}\right)$ & Rothera $\left(67^{\circ} \mathrm{S}\right)$ & Stat. value & $p$ value \\
\hline $\mathrm{C} 11: 0$ & $0.24 \pm 0.09(1.47)^{\mathrm{a}}$ & $0.13 \pm 0.02(1.19)^{b}$ & $0.19 \pm 0.04(2.51)^{\mathrm{a}}$ & 22.03 & $<0.001$ \\
\hline $\mathrm{C} 12: 0$ & $0.29 \pm 0.05(1.78)^{\mathrm{a}}$ & $0.25 \pm 0.03(2.29)^{\mathrm{b}}$ & $0.25 \pm 0.03(3.30)^{b}$ & 10.22 & $<0.01$ \\
\hline C13:0 & $0.26 \pm 0.08(1.59)^{\mathrm{a}}$ & $0.16 \pm 0.02(1.46)^{b}$ & $0.27 \pm 0.07(3.56)^{\mathrm{a}}$ & 30.21 & $<0.001$ \\
\hline $\mathrm{C} 14: 0$ & $0.65 \pm 0.21(3.98)^{\mathrm{a}}$ & $0.48 \pm 0.04(4.39)^{\mathrm{ab}}$ & $0.37 \pm 0.10(4.88)^{b}$ & 20.71 & $<0.001$ \\
\hline C15:0 & $0.24 \pm 0.07(1.47)^{\mathrm{a}}$ & $0.20 \pm 0.05(1.83)^{\mathrm{a}}$ & $0.19 \pm 0.05(2.51)^{\mathrm{a}}$ & 6.38 & $<0.05$ \\
\hline $\mathrm{C} 16: 0$ & $4.60 \pm 1.42(28.17)^{\mathrm{a}}$ & $2.58 \pm 0.65(23.6)^{b}$ & $2.14 \pm 0.55(28.23)^{b}$ & 30.18 & $<0.001$ \\
\hline $\mathrm{C} 17: 0$ & $0.49 \pm 0.14(3.00)^{\mathrm{a}}$ & $0.32 \pm 0.12(2.93)^{\mathrm{b}}$ & $0.15 \pm 0.03(1.98)^{\mathrm{c}}$ & 39.25 & $<0.001$ \\
\hline C18:0 & $2.19 \pm 0.47(13.41)^{\mathrm{a}}$ & $1.30 \pm 0.30(11.89)^{\mathrm{b}}$ & $1.27 \pm 0.38(16.75)^{\mathrm{b}}$ & 36.65 & $<0.001$ \\
\hline $\mathrm{C} 20: 0$ & $0.62 \pm 0.12(3.80)$ & 0 & 0 & - & - \\
\hline $\mathrm{C} 22: 0$ & 0 & $0.31 \pm 0.11(2.84)$ & 0 & - & - \\
\hline $\mathrm{C} 23: 0$ & $0.43 \pm 0.09(2.63)^{\mathrm{a}}$ & $0.27 \pm 0.10(2.47)^{\mathrm{b}}$ & $0.34 \pm 0.03(4.49)^{\mathrm{b}}$ & 26.39 & $<0.001$ \\
\hline Total SFA & $10.01 \pm 1.35(61.30)^{\mathrm{a}}$ & $6.00 \pm 0.76(54.89)^{\mathrm{b}}$ & $5.17 \pm 0.65(68.21)^{b}$ & 58.27 & $<0.001$ \\
\hline $\mathrm{C} 14: 1 n-5$ & $0.67 \pm 0.28(4.10)^{\mathrm{a}}$ & $0.72 \pm 0.17(6.59)^{\mathrm{a}}$ & $0.21 \pm 0.02(2.76)^{b}$ & 28.31 & $<0.001$ \\
\hline $\mathrm{C} 16: 1 n-9$ & $0.72 \pm 0.38(4.42)^{\mathrm{a}}$ & $0.60 \pm 0.27(5.49)^{\mathrm{a}}$ & $0.22 \pm 0.09(2.90)^{b}$ & 24.71 & $<0.001$ \\
\hline C18:1n-9 & $1.06 \pm 0.39(6.49)^{\mathrm{a}}$ & $1.85 \pm 0.25(16.93)^{b}$ & $0.46 \pm 0.11(6.07)^{\mathrm{c}}$ & 45.04 & $<0.001$ \\
\hline C20:1 & $0.99 \pm 0.33(6.06)$ & 0 & 0 & - & - \\
\hline $\mathrm{C} 22: 1 n-9$ & 0 & $0.17 \pm 0.05(1.56)^{\mathrm{a}}$ & $0.15 \pm 0.03(1.98)^{\mathrm{a}}$ & 97.00 & 0.12 \\
\hline Total MUFA & $3.44 \pm 0.42(21.07)^{\mathrm{a}}$ & $3.34 \pm 0.72(30.56)^{\mathrm{a}}$ & $1.04 \pm 0.17(13.72)^{b}$ & 32.80 & $<0.001$ \\
\hline $\mathrm{C} 18: 2 n-6 \mathrm{c}$ & $0.32 \pm 0.12(1.96)^{\mathrm{a}}$ & $0.21 \pm 0.08(1.92)^{b}$ & 0 & 94.50 & $<0.01$ \\
\hline $\mathrm{C} 18: 2 n-6 \mathrm{t}$ & $0.24 \pm 0.09(1.47)^{\mathrm{a}}$ & $0.14 \pm 0.02(1.28)^{b}$ & $0.15 \pm 0.02(1.98)^{b}$ & 17.90 & $<0.001$ \\
\hline $\mathrm{C} 18: 3 n-6$ & $0.36 \pm 0.13(2.20)^{\mathrm{a}}$ & $0.21 \pm 0.04(1.92)^{b}$ & $0.14 \pm 0.02(1.85)^{\mathrm{c}}$ & 36.61 & $<0.001$ \\
\hline Total $n-6$ PUFA & $0.92 \pm 0.06(5.63)^{\mathrm{a}}$ & $0.56 \pm 0.04(5.12)^{b}$ & $0.29 \pm 0.08(3.83)^{\mathrm{c}}$ & 46.29 & $<0.001$ \\
\hline $\mathrm{C} 20: 3 n-3$ & $0.43 \pm 0.13(2.63)^{\mathrm{a}}$ & $0.25 \pm 0.07(2.29)^{b}$ & $0.14 \pm 0.03(1.85)^{\mathrm{c}}$ & 42.81 & $<0.001$ \\
\hline $\mathrm{C} 20: 5 n-3$ & $1.03 \pm 0.51(6.31)^{\mathrm{a}}$ & $0.42 \pm 0.19(3.84)^{b}$ & $0.59 \pm 0.43(7.78)^{b}$ & 17.69 & $<0.001$ \\
\hline $\mathrm{C} 22: 6 n-3$ & $0.50 \pm 0.18(3.06)^{\mathrm{a}}$ & $0.36 \pm 0.11(3.29)^{b}$ & $0.35 \pm 0.22(4.62)^{b}$ & 5.33 & $<0.01$ \\
\hline Total $n$-3 PUFA & $1.96 \pm 0.33(12.00)^{\mathrm{a}}$ & $1.03 \pm 0.09(9.43)^{\mathrm{b}}$ & $1.08 \pm 0.23(14.25)^{\mathrm{b}}$ & 23.85 & $<0.001$ \\
\hline Total PUFA & $2.88 \pm 0.28(17.64)^{\mathrm{a}}$ & $1.59 \pm 0.10(14.55)^{\mathrm{b}}$ & $1.37 \pm 0.21(18.07)^{\mathrm{b}}$ & 32.37 & $<0.001$ \\
\hline Total FA & $16.33 \pm 0.98(100)^{\mathrm{a}}$ & $10.93 \pm 0.63(100)^{b}$ & $7.58 \pm 0.48(100)^{\mathrm{c}}$ & 41.57 & $<0.001$ \\
\hline
\end{tabular}

Abbreviations are the following= SFA: saturated FA; MUFA: monounsaturated FA; PUFA: polyunsaturated FA; SFA= sum of C11:0, C12:0, C13:0, C14:0, C15:0, C16:0, C17:0, C18:0, C20:0, $\mathrm{C} 22: 0$ and $\mathrm{C} 23: 0 ; \mathrm{MUFA}=$ sum of $\mathrm{C} 14: 1 n-5, \mathrm{C} 16: 1 n-9, \mathrm{C} 18: 1 n-9, \mathrm{C} 20: 1$ and $\mathrm{C} 22: 1 n-9$; Total $n-6$ PUFA $=$ sum of C18:2n-6c, C18:2n-6t and C18:3n-6; Total $n-3$ PUFA $=$ sum of 20:3n-3, 20:5n-3 and 22:6n-3; Total PUFA $=$ sum of $n-3$ and $n-6$ PUFA; Total FA $=$ sum of Total SFA, Total MUFA and Total PUFA. 


\section{Table 2 (on next page)}

Similarity percentage analysis (SIMPER) used to evaluate the contribution of each fatty acid found in $A$. eightsii individuals collected in three different localities at the WAP. $n=$ 58. The table shows fatty acids that contribute more than $4 \%$ to dis

$\mathrm{OH}$ O'Higgins station, Ye Yelcho station, Ro Rothera station, Diss.\% percentage dissimilarity of each comparison, FA fatty acid, Av.Ab. average abundance of each fatty acid, Av. Diss. the average similarity that each fatty acid contributes, Diss./SD the proportion of similarity and standard deviation, Contr.\% the contribution of each fatty acid to the general dissimilarity, Cum.\% General additive dissimilarity. 
1 Table 2. Similarity percentage analysis (SIMPER) used to evaluate the contribution of each fatty acid 2 found in $A$. eightsii individuals collected in three different localities at the WAP. $n=58$. The table 3 shows fatty acids that contribute more than $4 \%$ to dissimilarity (Contr.\%) of each comparison.

4

\begin{tabular}{|c|c|c|c|c|c|c|c|c|}
\hline Locality & Diss.\% & FA & Av.Ab. 1 & Av.Ab. 2 & Av.Diss. & Diss./SD & Contr.\% & Cum.\% \\
\hline \multirow[t]{5}{*}{$\mathrm{OH}$ vs. $\mathrm{Ye}$} & 15.83 & $\mathrm{C} 20: 1$ & 0.99 & 0 & 2.97 & 12.59 & 18.76 & 18.76 \\
\hline & & C20:0 & 0.89 & 0 & 2.67 & 15.97 & 16.85 & 35.62 \\
\hline & & $\mathrm{C} 22: 0$ & 0 & 0.74 & 2.23 & 11.48 & 14.07 & 49.69 \\
\hline & & $\mathrm{C} 22: 1 n-9$ & 0 & 0.64 & 1.94 & 13.85 & 12.23 & 61.92 \\
\hline & & C20:5n-3 & 0.98 & 0.79 & 0.65 & 1.64 & 4.13 & 66.05 \\
\hline \multirow[t]{6}{*}{ OH vs. Ro } & 18.23 & $\mathrm{C} 20: 1$ & 0.99 & 0 & 3.20 & 12.56 & 17.55 & 17.55 \\
\hline & & C20:0 & 0.89 & 0 & 2.87 & 15.40 & 15.77 & 33.32 \\
\hline & & $\mathrm{C} 18: 2 n-6 \mathrm{c}$ & 0.74 & 0 & 2.41 & 9.85 & 13.24 & 46.56 \\
\hline & & $\mathrm{C} 22: 1 n-9$ & 0 & 0.62 & 2.01 & 21.96 & 11.02 & 57.58 \\
\hline & & $\mathrm{C} 16: 0$ & 1.45 & 1.20 & 0.82 & 1.81 & 4.48 & 62.07 \\
\hline & & $\mathrm{C} 16: 1 n-9$ & 0.90 & 0.67 & 0.74 & 1.77 & 4.04 & 66.11 \\
\hline \multirow[t]{6}{*}{ Ye vs. Ro } & 11.33 & $\mathrm{C} 22: 0$ & 0.74 & 0 & 2.54 & 11.72 & 22.42 & 22.42 \\
\hline & & $\mathrm{C} 18: 2 n-6 \mathrm{c}$ & 0.67 & 0 & 2.28 & 11.32 & 20.16 & 42.57 \\
\hline & & $\mathrm{C} 18: 1 n-9$ & 1.16 & 0.82 & 1.18 & 5.76 & 10.44 & 53.01 \\
\hline & & $\mathrm{C} 14: 1 n-5$ & 0.92 & 0.68 & 0.82 & 4.05 & 7.25 & 60.26 \\
\hline & & $\mathrm{C} 16: 1 n-9$ & 0.86 & 0.67 & 0.67 & 1.72 & 5.94 & 66.20 \\
\hline & & $\mathrm{C} 20: 5 n-3$ & 0.79 & 0.84 & 0.50 & 1.39 & 4.42 & 70.62 \\
\hline
\end{tabular}

5

$6 \mathrm{OH}$ O'Higgins station, Ye Yelcho station, Ro Rothera station, Diss.\% percentage dissimilarity of each 7 comparison, $F A$ fatty acid, $A v . A b$. average abundance of each fatty acid, $A v$. Diss. the average similarity 8 that each fatty acid contributes, Diss./SD the proportion of similarity and standard deviation, Contr.\% the 9 contribution of each fatty acid to the general dissimilarity, Cum.\% General additive dissimilarity. 


\section{Table 3 (on next page)}

Fatty acid biomarkers used for trophic relationships in benthic and pelagic marine environments. 
1 Table 3. Fatty acid biomarkers used for trophic relationships in benthic and pelagic marine 2 environments.

3

\begin{tabular}{lcc}
\hline Food source & Fatty acid biomarker & References \\
\hline Bacteria in general & Odd numbered SFA & Volkman et al., 1998 \\
Detritus & $\mathrm{C} 16: 0, \mathrm{C} 22: 0, \mathrm{C} 18: 0+\mathrm{C} 18: 1 n-9$ & Dalsgaard et al., 2003 \\
Green algae & $\mathrm{C} 18: 2 n-6, \mathrm{C} 18: 3 n-6$ & Cañavate, 2018 \\
Brown algae & $\mathrm{C} 18: 1 n-9, \mathrm{C} 18: 2 n-6, \mathrm{C} 20: 5 n-3, \mathrm{C} 16: 0$ & Zhukova, 2019 \\
Phaeocystis & $\mathrm{C} 18: 1 n-9, \mathrm{C} 18 \mathrm{PUFA}+\mathrm{C} 22: 6 n-3$ & Legeżyńska, Kędra \& Walkusz, 2014 \\
Heterotrophic flagellates & $\mathrm{C} 18: 2 n-6, \mathrm{C} 22: 6 n-3$ & Zhukova, 2019 \\
Flagellates in general & $\mathrm{C} 18 \mathrm{PUFA}+\mathrm{C} 22: 6 n-3$ & Legeżyńska, Kędra \& Walkusz, 2014 \\
Red algae & $\mathrm{C} 20: 5 n-3, \mathrm{C} 16: 0$ & Legeżyńska, Kędra \& Walkusz, 2014 \\
Meiofauna & $\mathrm{C} 22: 6 n-3, \mathrm{C} 18: 1 n-9$ & Zhukova, 2019 \\
Zooplankton (e.g. copepods) & $\mathrm{C} 20: 1, \mathrm{C} 22: 1 n-9$ & Kelly \& Scheibling, 2012 \\
Diatoms and dinoflagellates & $\mathrm{C} 22: 6 n-3, \mathrm{C} 20: 5 n-3$ & Dalsgaard et al., 2003; Cañavate, 2018 \\
\hline
\end{tabular}

4 Abbreviations (SFA: saturated fatty acid; PUFA: polyunsaturated fatty acid) 
Figure 1

Map of the A. eightsii sampling along the West Antarctic Peninsula (WAP). Filled circles indicate the northern, middle, and southern WAP sampling localities: O'Higgins Base $(\mathrm{OB})$, Yelcho (Ye) and Rothera (Ro), respectively.

Dashed arrows represent Southern Ocean currents, modified from Moffat \& Meredith (2018): Antarctic Circumpolar Current (ACC), Antarctic Peninsula Coastal Current (APCC), Coastal Current (CC).

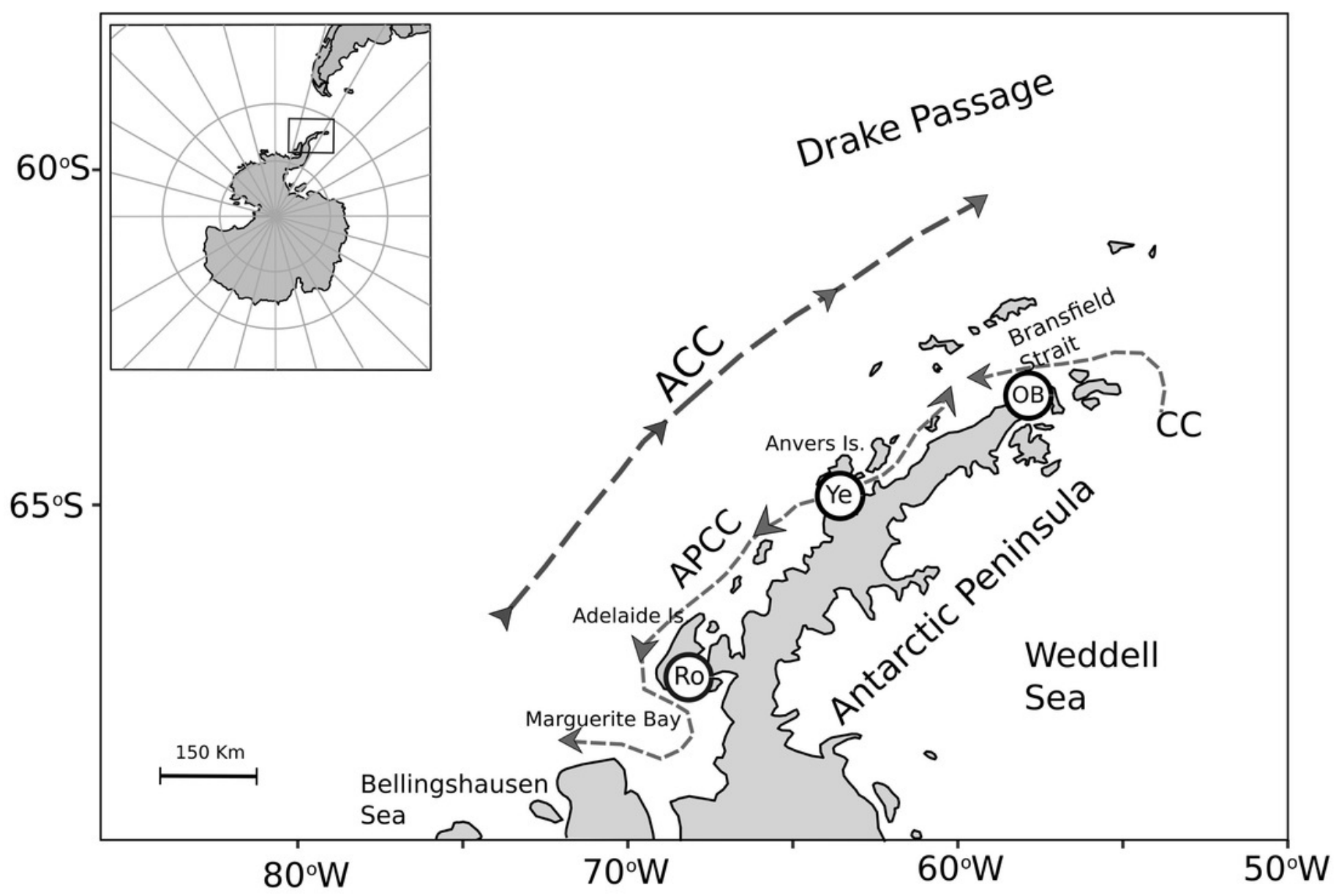




\section{Figure 2}

Jitter boxplot of (a) shell length ( $\mathrm{mm}$ ind. ${ }^{-1}$ ) and (b) tissue dry mass ( $\mathrm{mg}$ ind ${ }^{-1}$ ) of adult individuals of $A$. eightsii collected at three different localities of the WAP

Different letters on box indicate significant differences among sites after a multiple range test with a Bonferroni correction. In the boxplot, the horizontal end of the box nearer to zero represents the 25th percentile and the horizontal end of the box more distant from zero represents the 75th percentile. The horizontal black line within the box indicates the median and the red line within the box indicates the mean. Whiskers above and below the box represent 1.5 times the interquartile range from the box, respectively. Black circles above and below the whiskers are outliers. $n=58$. 

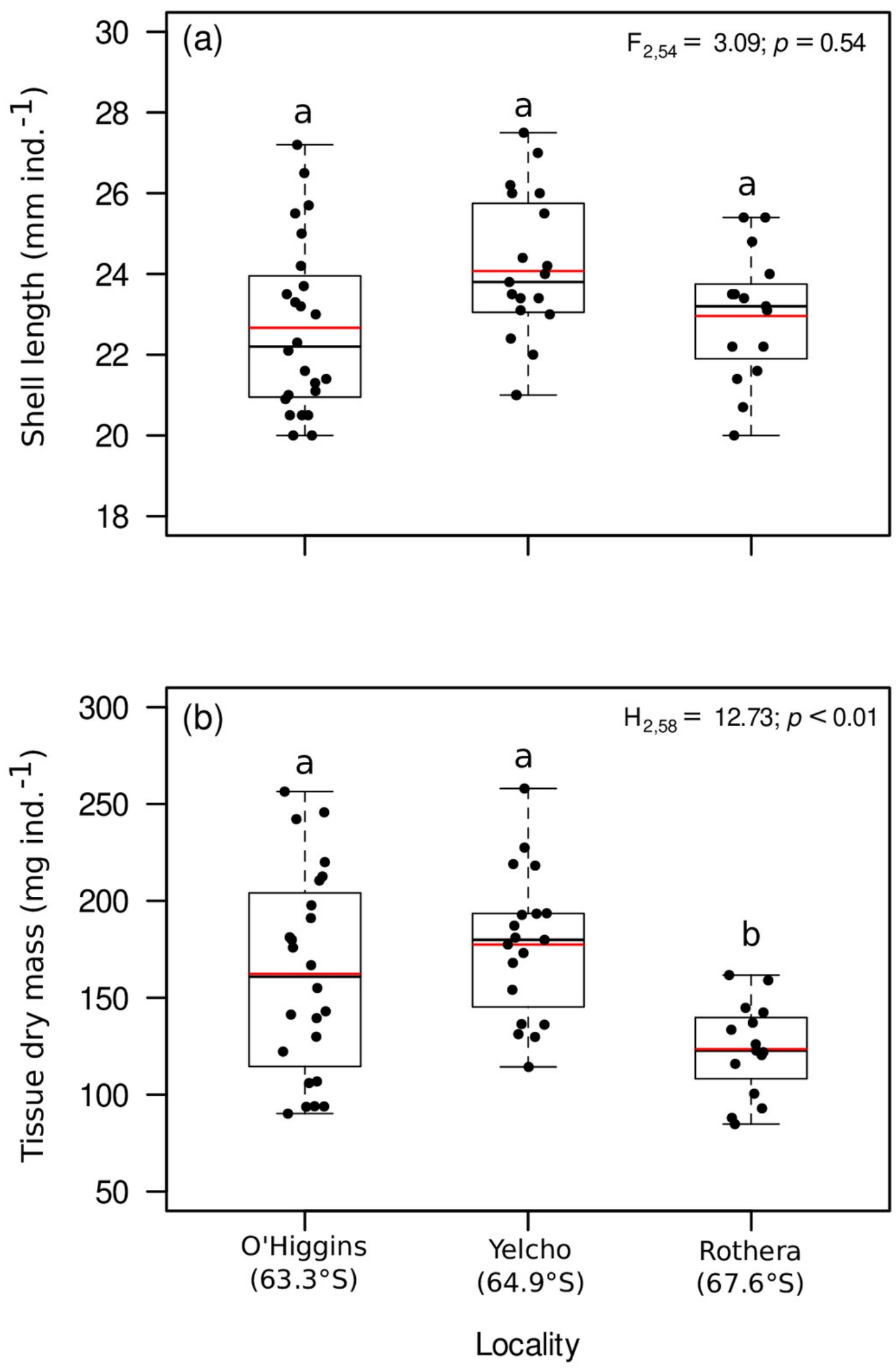


\section{Figure 3}

Jitter boxplot of (a) lipid content ( $\mathrm{mg}_{20} \mathrm{mg}^{-1}$ ), (b) lipid content (\% DM), (c) protein

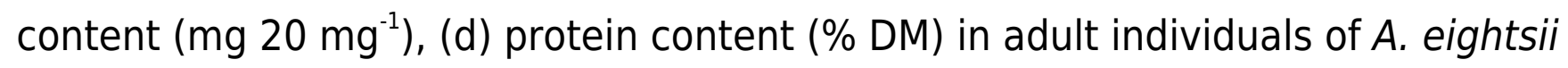
collected at three different localities of the WAP.

Different letters on box indicate significant differences among sites after a multiple range test with a Bonferroni correction. In the boxplot, the horizontal end of the box nearer to zero represents the 25th percentile and the horizontal end of the box more distant from zero represents the 75th percentile. The horizontal black line within the box indicates the median and the red line within the box indicates the mean. Whiskers above and below the box represent 1.5 times the interquartile range from the box, respectively. Black circles above and below the whiskers are outliers. $n=58$. 

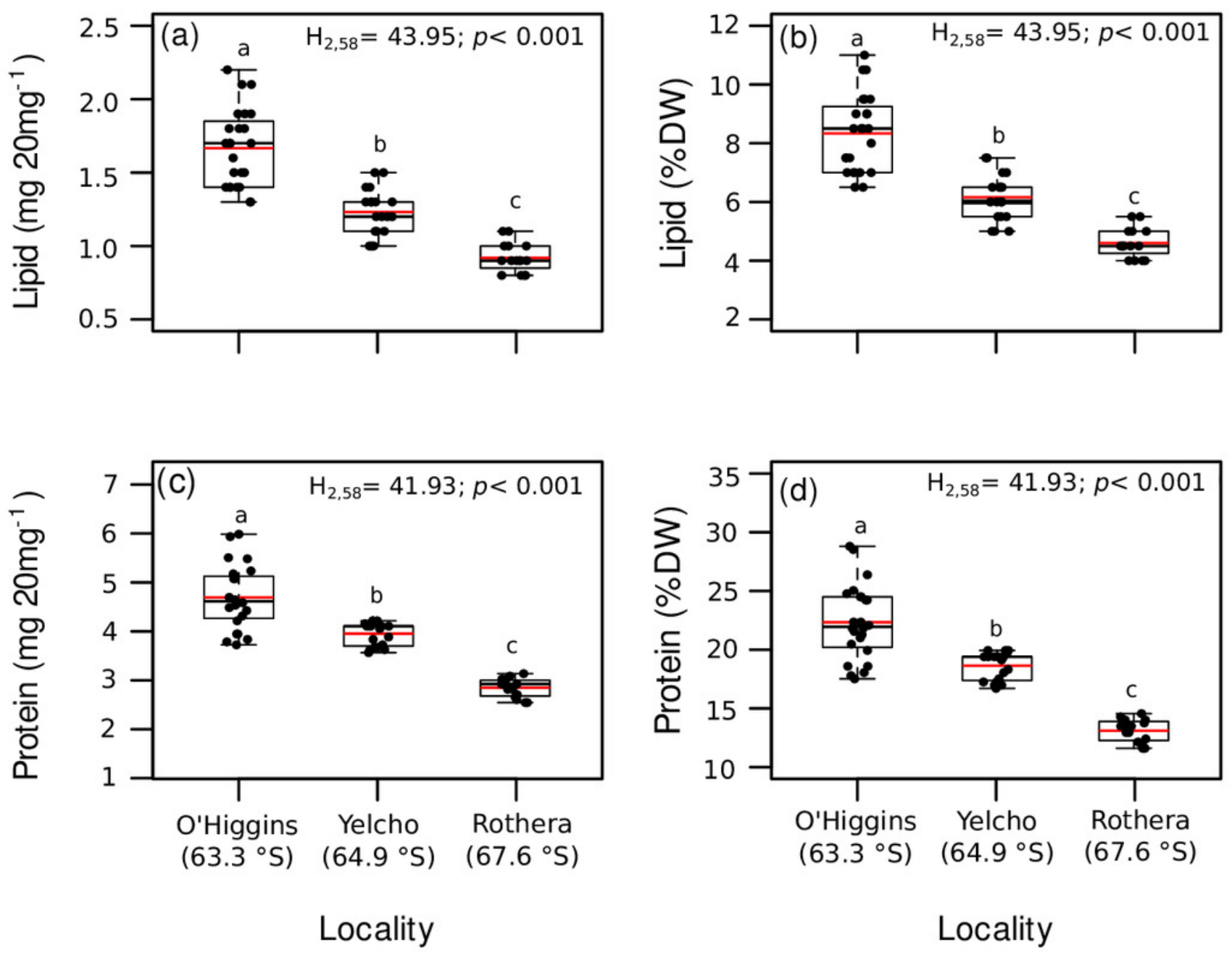


\section{Figure 4}

Jitter boxplot of the energy content ( $20 \mathrm{mg}^{-1}$ ) in adult individuals of $A$. eightsii collected at three different localities of the WAP.

Different letters on box indicate significant differences among sites after a multiple range test with a Bonferroni correction. In the boxplot, the horizontal end of the box nearer to zero represents the 25th percentile and the horizontal end of the box more distant from zero represents the 75th percentile. The horizontal black line within the box indicates the median and the red line within the box indicates the mean. Whiskers above and below the box represent 1.5 times the interquartile range from the box, respectively. Black circles above and below the whiskers are outliers. $n=58$. 


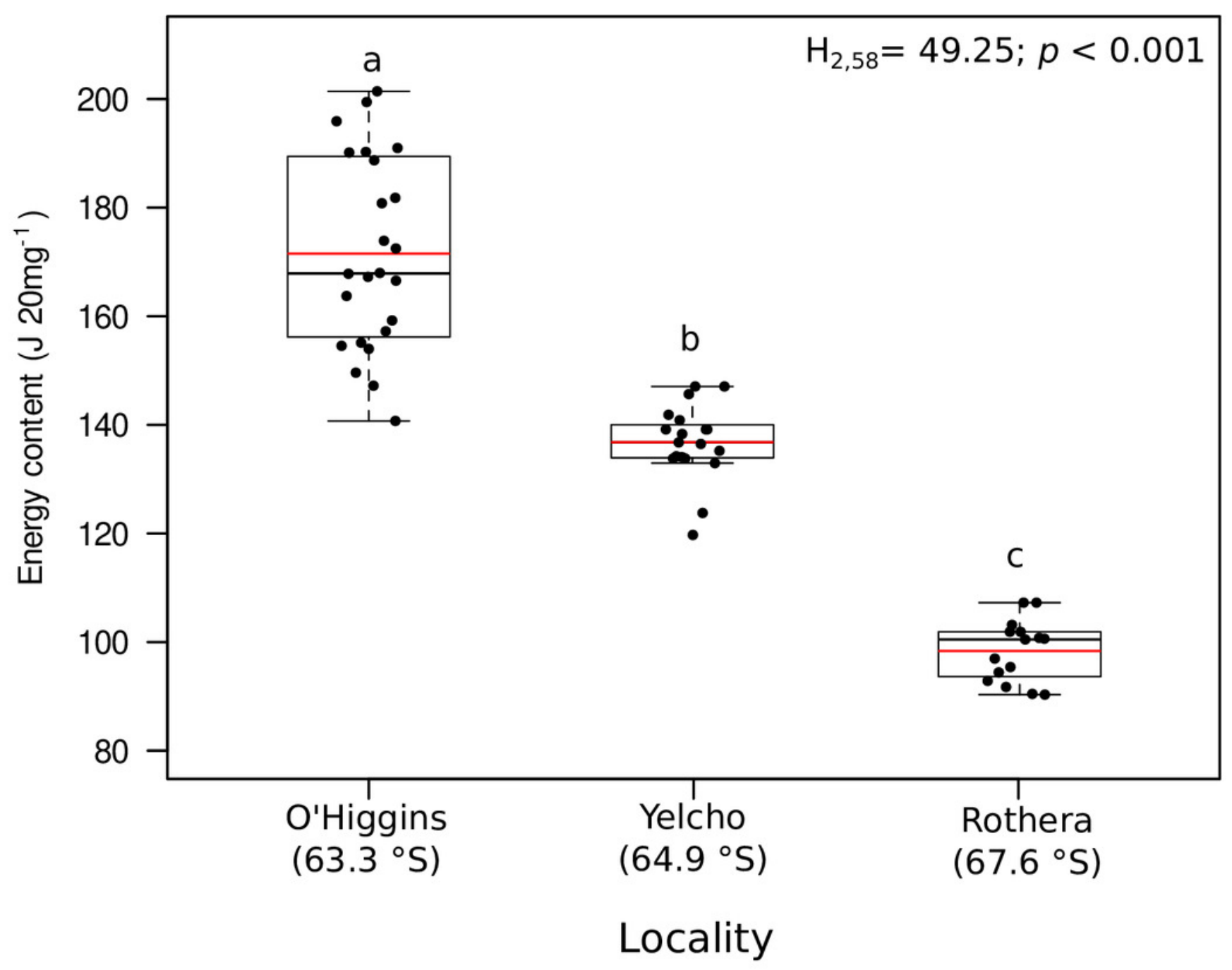


Figure 5

Principal component analysis (PCA) plot based on Bray-Curtis similarity of fatty acid data of adult individuals of $A$. eightsii collected at three different localities of the WAP.

Variables (fatty acids) are indicated in the vector plot according to Pearson correlation (> 0.9). PC1 axis explained $62.4 \%$ and PC2 explained $19.2 \%$ of the fatty acid profile between individuals from different localities.

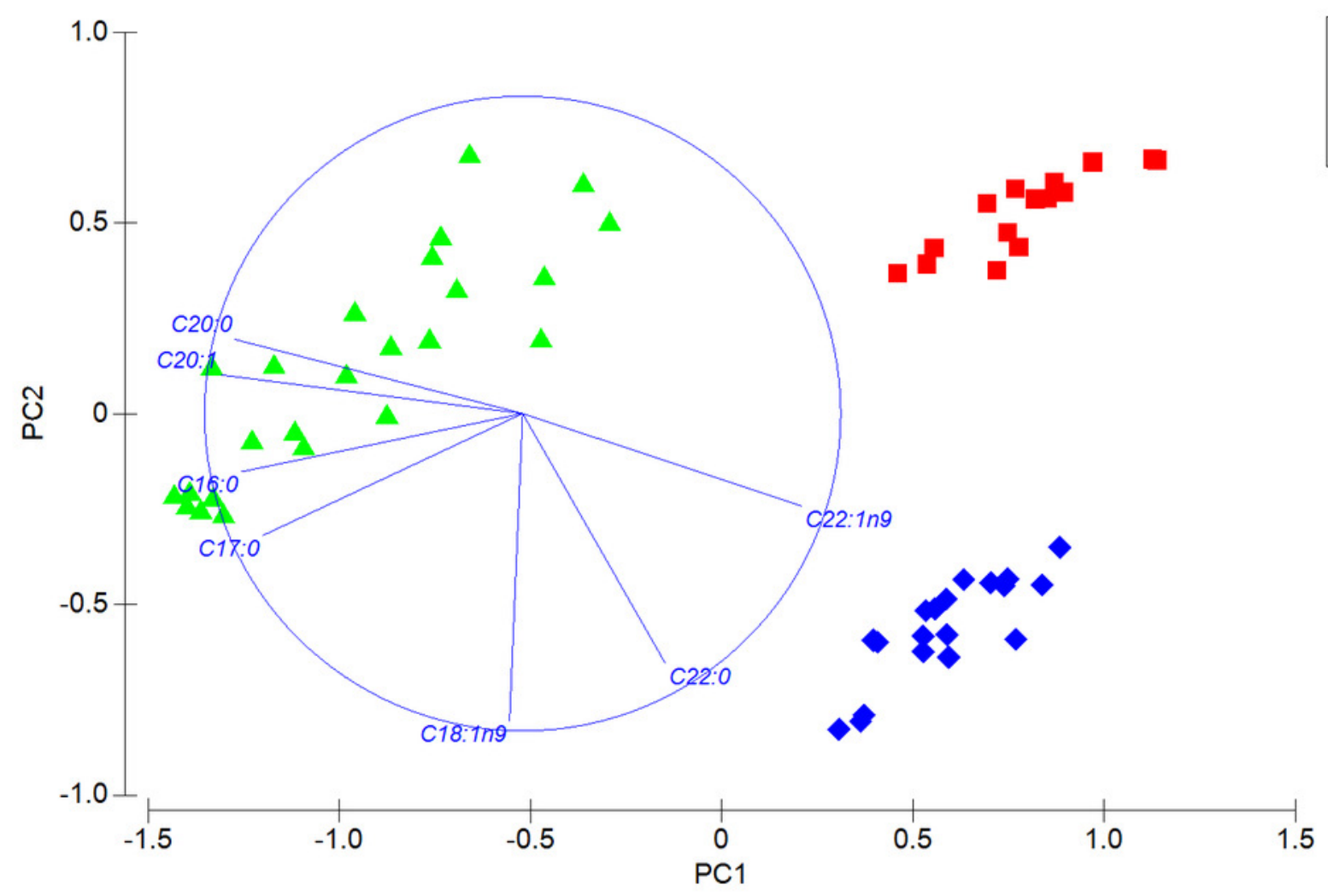

